Prepared in cooperation with the Federal Highway Administration and the Connecticut Department of Transportation

\title{
Preliminary Assessment of Chloride Concentrations, Loads, and Yields in Selected Watersheds along the Interstate 95 Corridor, Southeastern Connecticut, 2008-09
}

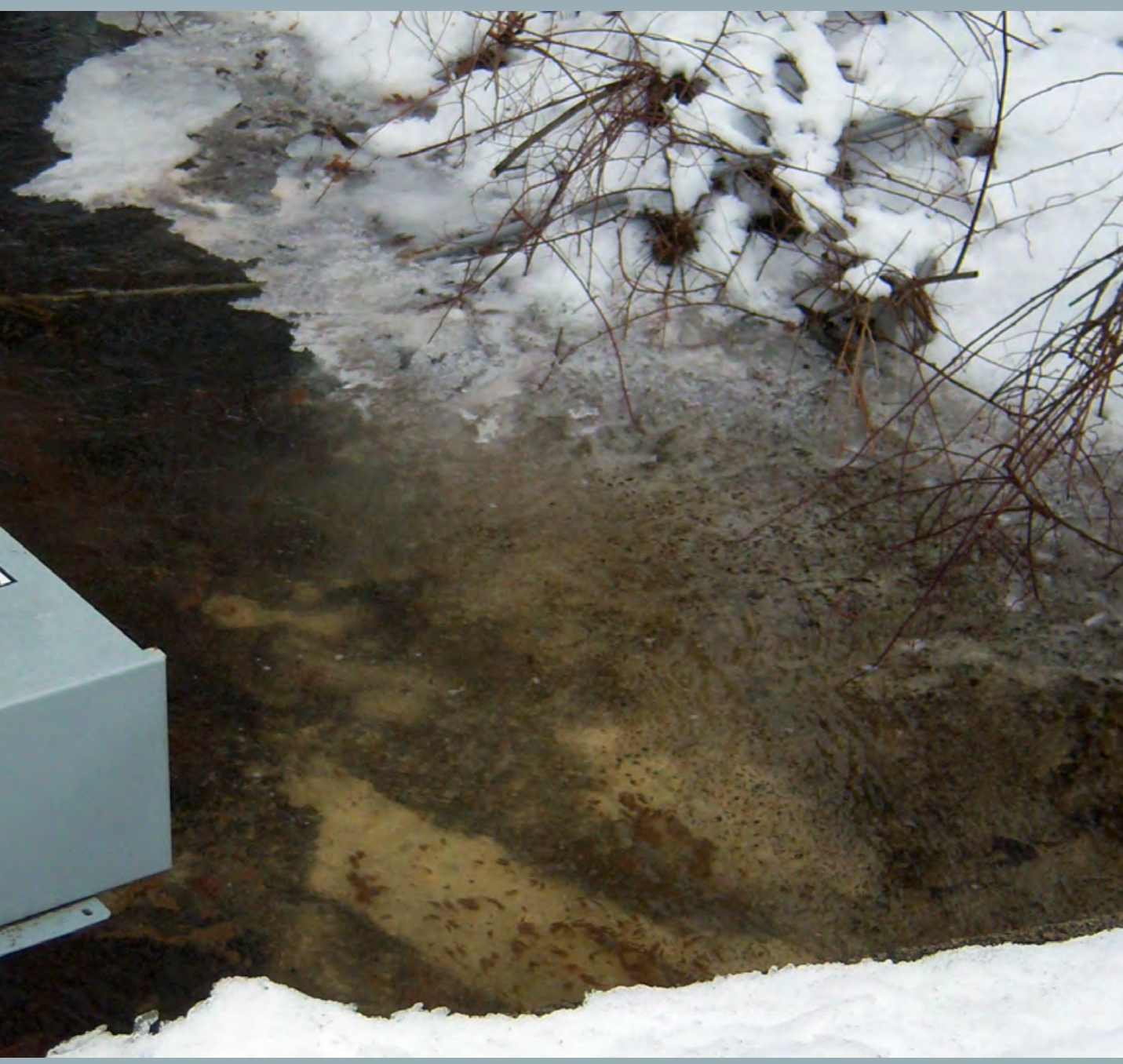

Open-File Report 2011-1018 
Cover. Photograph of the Oil Mill Brook downstream site in Waterford, Connecticut. 


\section{Preliminary Assessment of Chloride Concentrations, Loads, and Yields in Selected Watersheds along the Interstate 95 Corridor, Southeastern Connecticut, 2008-09}

By Craig J. Brown, John R. Mullaney, Jonathan Morrison, and Remo Mondazzi

Prepared in cooperation with the Federal Highway Administration and the Connecticut Department of Transportation

Open-File Report 2011-1018 


\title{
U.S. Department of the Interior \\ KEN SALAZAR, Secretary \\ U.S. Geological Survey \\ Marcia K. McNutt, Director
}

\section{U.S. Geological Survey, Reston, Virginia: 2011}

\author{
For more information on the USGS — the Federal source for science about the Earth, its natural and living resources, \\ natural hazards, and the environment, visit http://www.usgs.gov or call 1-888-ASK-USGS \\ For an overview of USGS information products, including maps, imagery, and publications, \\ visit http://www.usgs.gov/pubprod \\ To order this and other USGS information products, visit http://store.usgs.gov
}

\begin{abstract}
Any use of trade, product, or firm names is for descriptive purposes only and does not imply endorsement by the U.S. Government.

Although this report is in the public domain, permission must be secured from the individual copyright owners to reproduce any copyrighted materials contained within this report.
\end{abstract}

Suggested citation:

Brown, C.J., Mullaney, J. R., Morrison, Jonathan, and Mondazzi, Remo, 2011, Preliminary assessment of chloride concentrations, loads, and yields in selected watersheds along the Interstate 95 corridor, southeastern Connecticut, 2008-09: U.S. Geological Survey Open-File Report 2011-1018, 41 p. at http://pubs.usgs.gov/ofr/2011-1018/. 


\section{Contents}

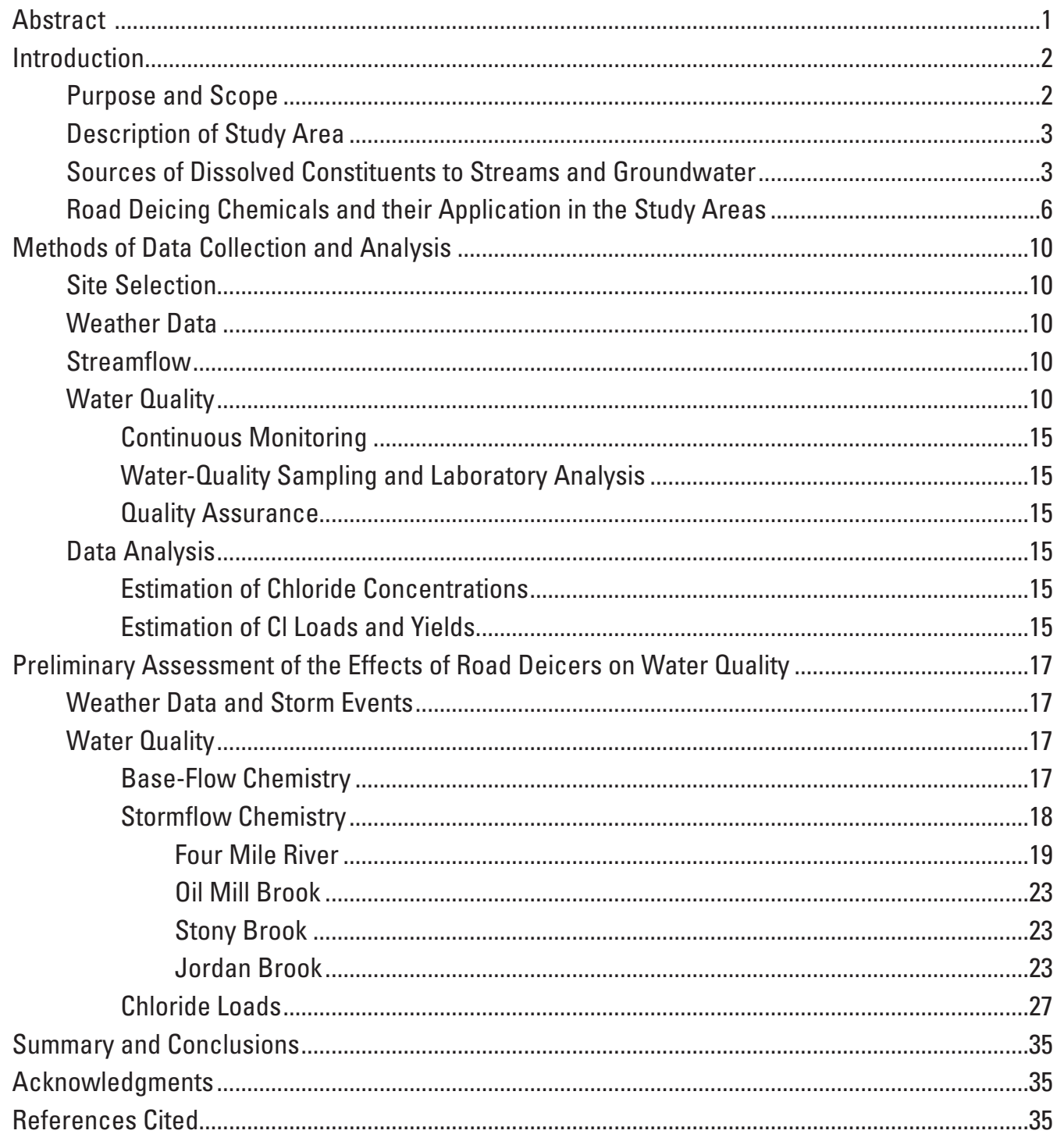

Appendix 1. Specific conductance and chloride concentrations in water samples from upstream and downstream monitoring sites at Four Mile River, Oil Mill Brook, Stony Brook, and Jordan

Brook, southeastern Connecticut, November 2008 to January 2010.

\section{Figures}

1. Map showing location of water-quality monitoring sites for this study, and sites on other rivers in Connecticut, and several weather stations, including the Groton-New London airport weather station, a Snow Observation weather station, and three National Atmospheric Deposition Program sites.

2. Map showing upstream and downstream water-quality monitoring sites and downstream streamgages on the four selected streams and their watersheds along the Interstate 95 corridor study area, southeastern Connecticut. 
3. Map showing water-quality monitoring sites and downstream streamgages, watershed boundaries, and deicing salt storage and landfill locations in the study areas, southeastern Connecticut.

4. Graph showing estimated monthly median chloride loads in atmospheric deposition based on three National Atmospheric Deposition Program stations, November 2008 - September 2009. Data are from National Atmospheric Deposition Program, 2009

5. Graph showing A, Maximum and minimum daily air temperature and continuous precipitation at the Groton-New London airport weather station, and B, estimated hourly snow thickness and snow melt at a snow observation station in southeastern Connecticut, November 2008-September 2009.

6. Graph showing continuous streamflow at the downstream monitoring sites at Four Mile River, Oil Mill Brook, Stony Brook, and Jordan Brook, and precipitation at Groton-New London airport weather station, southeastern Connecticut, November 2008-September 2009

7. Diagrams depicting the concentrations of major ions in water at upstream and downstream monitoring sites at Four Mile River, Oil Mill Brook, Stony Brook, and Jordan Brook, southeastern Connecticut, and shallow groundwater samples from wells in forested land-use settings in Connecticut.

8. Graphs showing A, Specific conductance in grab samples, continuous specific conductance at Four Mile River upstream and downstream sites, continuous streamflow at the downstream site, and precipitation at Groton-New London airport weather station, and $B$, chloride concentrations measured in grab samples and estimated continuous chloride concentrations at Four Mile River upstream and downstream sites, southeastern Connecticut, November 2008-September 2009

9. Graphs showing A, Specific conductance in grab samples and continuous specific conductance at Oil Mill Brook upstream and downstream sites, continuous streamflow at the downstream site, and precipitation at Groton-New London airport weather station, and B, chloride concentrations measured in grab samples and estimated continuous chloride concentrations at Oil Mill Brook upstream and downstream sites, southeastern Connecticut, November 2008-September 2009

10. Graphs showing A, Specific conductance in grab samples and continuous specific conductance at Stony Brook upstream and downstream sites, continuous streamflow at the downstream site, and precipitation at Groton-New London airport weather station, and $B$, chloride concentrations measured in grab samples and estimated continuous chloride concentrations at Stony Brook upstream and downstream sites, southeastern Connecticut, November 2008-September 2009

11. Graphs showing $A$, specific conductance in grab samples and continuous specific conductance at Jordan Brook upstream and downstream sites, continuous streamflow at the downstream site, and precipitation at Groton-New London airport weather station, and $B$, chloride concentrations measured in grab samples and estimated continuous chloride concentrations at Jordan Brook upstream and downstream sites, southeastern Connecticut, November 2008-September 2009

12. Graphs showing A, estimated daily mean chloride concentrations at Four Mile River upstream and downstream sites, and B, estimated daily mean chloride load and streamflow for the Four Mile River downstream site, southeastern Connecticut, November 2008-September 2009

13. Graphs showing A, estimated daily mean chloride concentrations at Oil Mill Brook upstream and downstream sites, and B, estimated daily mean chloride load and streamflow for the Oil Mill Brook downstream site, southeastern Connecticut, November 2008-September 2009. 
14. Graphs showing A, estimated daily mean chloride concentrations at Stony Brook upstream and downstream sites, and B, estimated daily mean chloride load and streamflow for the Stony Brook downstream site, southeastern Connecticut, November 2008-September 2009.

15. Graphs showing A, estimated daily mean chloride concentrations at Jordan Brook upstream and downstream sites, and B, estimated daily mean chloride load and streamflow for the Jordan Brook downstream site, southeastern Connecticut, November 2008-September 2009.

16. Diagram showing distribution of annual chloride yields estimated using LOADEST for selected rivers in Connecticut for water years 1998-2007, and estimated annual chloride yields for the downstream sites at Four Mile River, Oil Mill Brook, Stony Brook, and Jordan Brook for their periods of record

17. Graph showing percentage of impervious cover as a function of (1) the chloride yields for the downstream monitoring stations at Four Mile River, Oil Mill Brook, Stony Brook, and Jordan Brook during the periods of record for this study, and (2) the median of the mean chloride yields at other selected rivers in Connecticut during water years 1998-2007

\section{Tables}

1. Land use, numbers of salt-storage facilities and landfills, and percentage of impervious area for four selected watersheds, southeastern Connecticut.

2. Classification of surficial materials for watersheds above each monitoring site in the study area, southeastern Connecticut.

3. Estimated atmospheric deposition yields and loads of chloride for the four selected watersheds in southeastern Connecticut. Loads were computed from National Atmospheric Deposition Program station

4. Description of two areas of Interstate 95 in which the deicing chemicals were applied to state-operated roads within areas of (1) the Four Mile River watershed, and (2) the combined Oil Mill Brook, Stony Brook, and Jordan Brook watersheds, southeastern Connecticut.

5. Description of the applications of deicing materials to state-operated roads during winter storms and deicing activities within the areas of (1) the Four Mile River watershed, and (2) the Oil Mill Brook, Stony Brook, and Jordan Brook area watersheds, southeastern Connecticut, for the 2008-09 winter seasons, and summaries for the 2006-07 and 2007-08 winter seasons

6. Deicing materials applied to town roads during the 2008-09 winter season, southeastern Connecticut.

7. Multiple linear regression estimates of model coefficients and standard errors, t-statistics, and $p$-values for the dependent variable chloride concentration at monitoring sites upstream and downstream from Interstate 95, southeastern Connecticut.

8. Summary statistics for $A$, specific conductance and B, estimated chloride concentrations for continuous data, and grab samples at the eight monitoring sites, southeastern Connecticut, November 2008-September 2009

9A. Estimated mean chloride loads for streams at the four monitoring sites downstream from Interstate 95, southeastern Connecticut, November 2008 to January 2010

9B. Estimated mean chloride loads for streams, atmospheric deposition, and deicers applied to town and state roads in the study areas of the Four Mile River watershed and the Oil Mill Brook-Stony Brook-Jordan Brook watersheds, November 2008 to January 2010 


\begin{tabular}{|c|c|c|}
\hline Multiply & By & To obtain \\
\hline \multicolumn{3}{|c|}{ Length } \\
\hline inch (in.) & 2.54 & centimeter $(\mathrm{cm})$ \\
\hline inch (in.) & 25.4 & millimeter (mm) \\
\hline foot (ft) & 0.3048 & meter (m) \\
\hline mile (mi) & 1.609 & kilometer $(\mathrm{km})$ \\
\hline \multicolumn{3}{|c|}{ Area } \\
\hline square mile $\left(\mathrm{mi}^{2}\right)$ & 2.590 & square kilometer $\left(\mathrm{km}^{2}\right)$ \\
\hline \multicolumn{3}{|c|}{ Volume } \\
\hline gallon (gal) & 3.785 & liter (L) \\
\hline gallon (gal) & 0.003785 & cubic meter $\left(\mathrm{m}^{3}\right)$ \\
\hline \multicolumn{3}{|c|}{ Flow rate } \\
\hline cubic foot per second $\left(\mathrm{ft}^{3} / \mathrm{s}\right)$ & 0.02832 & cubic meter per second $\left(\mathrm{m}^{3} / \mathrm{s}\right)$ \\
\hline inch per year (in/yr) & 25.4 & millimeter per year $(\mathrm{mm} / \mathrm{yr})$ \\
\hline \multicolumn{3}{|c|}{ Mass } \\
\hline pound, avoirdupois (lb) & 0.4536 & kilogram $(\mathrm{kg})$ \\
\hline ton, short $(2,000 \mathrm{lb})$ & 0.9072 & megagram $(\mathrm{Mg})$ \\
\hline ton per day (ton/d) & 0.9072 & metric ton per day \\
\hline ton per day (ton/d) & 0.9072 & megagram per day $(\mathrm{Mg} / \mathrm{d})$ \\
\hline $\begin{array}{l}\text { ton per day per square mile } \\
{\left[(\text { ton } / \mathrm{d}) / \mathrm{mi}^{2}\right]}\end{array}$ & 0.3503 & $\begin{array}{l}\text { megagram per day per square kilome- } \\
\text { ter }\left[(\mathrm{Mg} / \mathrm{d}) / \mathrm{km}^{2}\right]\end{array}$ \\
\hline
\end{tabular}

Temperature in degrees Celsius $\left({ }^{\circ} \mathrm{C}\right)$ may be converted to degrees Fahrenheit $\left({ }^{\circ} \mathrm{F}\right)$ as follows:

$$
{ }^{\circ} \mathrm{F}=\left(1.8 x^{\circ} \mathrm{C}\right)+32
$$

Temperature in degrees Fahrenheit $\left({ }^{\circ} \mathrm{F}\right)$ may be converted to degrees Celsius $\left({ }^{\circ} \mathrm{C}\right)$ as follows:

$$
{ }^{\circ} \mathrm{C}=\left({ }^{\circ} \mathrm{F}-32\right) / 1.8
$$

Vertical coordinate information is referenced to the North American Vertical Datum of 1988 (NAVD 88).

Horizontal coordinate information is referenced to the North American Datum of 1983 (NAD 83).

Altitude, as used in this report, refers to distance above the vertical datum.

* Specific conductance is given in microsiemens per centimeter at 25 degrees Celsius $\left(\mu \mathrm{S} / \mathrm{cm}\right.$ at $\left.25^{\circ} \mathrm{C}\right)$.

Concentrations of chemical constituents in water are given in milligrams per liter (mg/L).

List of Abbreviations

ConnDOT Connecticut Department of Transportation

EIS Environmental Impact Statement

FHWA Federal Highway Administration

USGS U.S. Geological Survey

USEPA U.S. Environmental Protection Agency 


\title{
Preliminary Assessment of Chloride Concentrations, Loads, and Yields in Selected Watersheds along the Interstate 95 Corridor, Southeastern Connecticut, 2008-09
}

\author{
By Craig J. Brown, John R. Mullaney, Jonathan Morrison, and Remo Mondazzi
}

\begin{abstract}
Water-quality conditions were assessed to evaluate potential effects of road-deicer applications on stream-water quality in four watersheds along Interstate 95 (I-95) in southeastern Connecticut from November 1, 2008, through September 30, 2009. This preliminary study is part of a four-year cooperative study by the U.S. Geological Survey (USGS), the Federal Highway Administration (FHWA), and the Connecticut Department of Transportation (ConnDOT). Streamflow and water quality were studied at four watersheds-Four Mile River, Oil Mill Brook, Stony Brook, and Jordan Brook. Water-quality samples were collected and specific conductance was measured continuously at paired water-quality monitoring sites upstream and downstream from I-95. Specific conductance values were related to chloride (Cl) concentrations to assist in determining the effects of road-deicing operations on the levels of $\mathrm{Cl}$ in the streams. Streamflow and water-quality data were compared with weather data and with the timing, amount, and composition of deicers applied to state highways. Grab samples were collected during winter stormwater-runoff events, such as winter storms or periods of rain or warm temperatures in which melting takes place, and periodically during the spring and summer.

$\mathrm{Cl}$ concentrations at the eight water-quality monitoring sites were well below the U.S. Environmental Protection Agency (USEPA) recommended chronic and acute $\mathrm{Cl}$ toxicity criteria of 230 and 860 milligrams per liter $(\mathrm{mg} / \mathrm{L})$, respectively. Specific conductance and estimated $\mathrm{Cl}$ concentrations in streams, particularly at sites downstream from I-95, peaked during discharge events in the winter and early spring as a result of deicers applied to roads and washed off by stormwater or meltwater. During winter storms, deicing activities, or subsequent periods of melting, specific conductance and estimated $\mathrm{Cl}$ concentrations peaked as high as 703 microsiemens per centimeter $(\mu \mathrm{S} / \mathrm{cm})$ and $160 \mathrm{mg} / \mathrm{L}$ at the downstream sites.
\end{abstract}

During most of the spring and summer, specific conductance and estimated $\mathrm{Cl}$ concentrations decreased during discharge events because the low-ionic strength of stormwater had a diluting effect on stream-water quality. However, peaks in specific conductance and estimated $\mathrm{Cl}$ concentrations at Jordan Brook and Stony Brook corresponded to peaks in streamflow well after winter snow or ice events; these delayed peaks in $\mathrm{Cl}$ concentration likely resulted from deicing salts that remained in melting snow piles and (or) that were flushed from soils and shallow groundwater, then discharged downstream.

$\mathrm{Cl}$ loads in streams generally were highest in the winter and early spring. The estimated load for the period of record at the four monitoring sites downstream from I-95 ranged from 0.33 ton per day (ton/d) at the Stony Brook watershed to 0.59 ton/d at the Jordan Brook watershed. The $\mathrm{Cl}$ yields ranged from 0.07 ton per day per square mile (ton/d/) $\mathrm{mi}^{2}$ ) at Oil Mill Brook, one of the least developed watersheds, to $0.21(\mathrm{ton} / \mathrm{d}) / \mathrm{mi}^{2}$ ) at Jordan Brook, the watershed with the highest percentage of urban development and impervious surfaces. The median estimates of $\mathrm{Cl}$ load from atmospheric deposition ranged from 11 to 19 tons, and contributed 4.3 to 7.1 percent of the $\mathrm{Cl}$ load in streamflow from the watershed areas. A comparison of the $\mathrm{Cl}$ load input and output estimates indicates that less $\mathrm{Cl}$ is leaving the watersheds than is entering through atmospheric deposition and application of deicers. The lag time between introduction of $\mathrm{Cl}$ to the watershed and transport to the stream, and uncertainty in the load estimates may be the reasons for this discrepancy. In addition, estimates of direct infiltration of $\mathrm{Cl}$ to groundwater from atmospheric deposition, deicer applications, and septic-tank drainfields to groundwater were outside the scope of the November 2008 to September 2009 assessment. However, increased concentrations of ions were observed between upstream and downstream sites and could result from deicer applications.

$\mathrm{Cl}$ yields per square mile at the downstream monitoring sites at each of the four streams were compared with $\mathrm{Cl}$ yield estimates for 10 selected rivers in Connecticut. Four 
Mile River and Oil Mill Brook had low estimated $\mathrm{Cl}$ yields, similar to yields at Bunnell (Burlington) Brook and Shetucket River, that reflect the low percentages of developed land and impervious area. Estimated $\mathrm{Cl}$ yields at Jordan Brook and Stony Brook were relatively high but were not as high as those in more urbanized watersheds such as those that drain the Still River at Brookfield Center and the Hockanum River. $\mathrm{Cl}$ yields for these sites were positively correlated with the percentage of impervious cover and probably reflect the application of deicers to roadways, as well as sources and practices associated with greater impervious cover, such as wastewater and septic-system discharges, and leachate from landfills and salt-storage areas.

\section{Introduction}

The Federal Highway Administration (FHWA) and the Connecticut Department of Transportation (ConnDOT) are developing an Environmental Impact Statement (EIS) for the expansion of Interstate 95 (I-95) between Old Lyme and New London, Conn. Concerns have been raised by the U.S. Environmental Protection Agency (USEPA) about the effects of highway expansion on the water quality and biological resources associated with streams crossed by I-95. Of particular concern are the water-quality changes that could result from expansion of impervious areas that require deicing and the subsequent changes in concentrations of chloride $(\mathrm{Cl})$ and other ions and loads of $\mathrm{Cl}$ to streams.

A primary concern regarding road-deicing practices is the degradation of surface water and groundwater that may be used for aquatic habitat or for drinking-water supply. The USEPA-recommended chronic criterion for aquatic life is a 4-day average $\mathrm{Cl}$ concentration of $230 \mathrm{mg} / \mathrm{L}$ with an occurrence interval of once every 3 years, and the recommended acute criterion concentration for $\mathrm{Cl}$ is $860 \mathrm{mg} / \mathrm{L}$ (U.S. Environmental Protection Agency, 1988). The latter criterion relates to a 1-hour average concentration with a recurrence interval of less than once every 3 years. The Connecticut Department of Environmental Protection (CTDEP) has recently proposed revisions to the standards for aquatic-life criteria for $\mathrm{Cl}$ that are identical to the USEPA standards (Connecticut Department of Environmental Protection, 2009). The USEPA has set a Secondary Maximum Contaminant Level (SMCL) of $250 \mathrm{mg} / \mathrm{L}$ for $\mathrm{Cl}$ in drinking water (U.S. Environmental Protection Agency, 1992). The $\mathrm{SMCL}$ for $\mathrm{Cl}$ is an unenforceable guideline that relates to the aesthetics of the water and the perceived salty taste of water at concentrations above $250 \mathrm{mg} / \mathrm{L}$. Another concern regarding salt inputs is the effects of cation-exchange reactions, which result in the release of other constituents from soils that can be detrimental to the quality of water (Granato and others, 1995).

Widespread upward trends in $\mathrm{Cl}$ concentrations in streams have been reported nationwide and may be related to a variety of factors, including increased road area and consequent deicing, increased wastewater and septic-system discharges, livestock waste and fertilizers, and leachate from landfills and salt-storage areas (Smith and others, 1987; Mullaney and others, 2009). Similar trends have been reported in Connecticut from the 1970s to 1990s (Trench, 1996; Colombo and Trench, 2002). Elevated concentrations of $\mathrm{Cl}$ and sodium $(\mathrm{Na})$ in glacial aquifers in Connecticut have been related to urban land use (Grady, 1993; Grady and Mullaney, 1998). A dramatic increase in the use of salt in the United States since 1950 (Kostick, 1993; Kostick and others, 2007) primarily results from the use of salt for deicing of roads, parking lots, and other impervious surfaces during the winter months. The use of salt for deicing has raised awareness of potential adverse effects of its use and application on water resources (Ramakrishna and Viraraghavan, 2005; Kaushal and others, 2005; Kelly and others, 2010).

ConnDOT has recently adopted (2007-08) new roaddeicing practices to reduce the use of sand for traction control and to increase the use of pretreatment sodium chloride $(\mathrm{NaCl})$ brine before storms (Connecticut Department of Transportation, 2009). ConnDOT also began using halite, amended with liquid calcium chloride $\left(\mathrm{CaCl}_{2}\right)$, for ice or snow events during 2007-08.

Effects of road deicers on water quality can be monitored effectively through continuous records of specific conductance, together with periodic solute analysis, and continuous estimates of streamflow (Gurnell and others, 1994; Granato and Smith, 1999). Additional knowledge of the use of salt, including the timing, amount, and composition of deicers applied to roadways, as well as the weather details, is beneficial in understanding the effects of road-salt wash off on concentrations and loads of $\mathrm{Cl}$ in streamflow. Collection of data to determine the $\mathrm{Cl}$ concentrations and streamflow, and how they affect specific conductance, is important to the development of a regression model to estimate $\mathrm{Cl}$ concentrations.

A study is being conducted by the U.S. Geological Survey (USGS), in cooperation with the FHWA and ConnDOT, to assess the water quality of streams and the effects of deicing of roads on stream-water quality. This is an interim report on that study and covers November 2008 through September 2009. The data collected for this study will be useful in understanding the water-quality implications of an I-95 expansion and can be used to assist in development of low-impact design alternatives.

\section{Purpose and Scope}

This interim report, which covers part of the 2008-09 winter season as well as the spring and summer of 2009, describes the collection and analysis of geologic, hydrologic, and water-quality data to assess baseline water-quality conditions along the I-95 corridor; the data can be used to develop an EIS on water quality. Specific conductance and $\mathrm{Cl}$ concentration data cover a longer period, 2008 to January 
2010, at some sites and were used to improve the regression models. This report describes the effects of upstream land use on stream-water quality, the variations in concentrations and loads of $\mathrm{Cl}$ during winter storms or deicing activities, and concentrations and loads of $\mathrm{Cl}$ during base-flow conditions. Other major ions also are discussed. Baseline water-quality data were collected to evaluate the water-quality conditions in streams crossed by I-95 and to evaluate sources of $\mathrm{Cl}$ delivered from I-95 and upstream areas. Specific conductance, which was measured continuously, was used as a surrogate to estimate $\mathrm{Cl}$ concentrations. These data were used to determine whether $\mathrm{Cl}$ concentrations frequently exceeded recommended water-quality criteria for protection of aquatic life in watersheds that are typical of many parts of Connecticut. This report also describes the sampling sites in detail, as well as the collection of water stage and streamflow data, continuous water-quality monitoring, and water-quality sampling.

\section{Description of Study Area}

The study area encompasses four watersheds in southeastern Connecticut crossed by I-95-Four Mile River, Oil Mill Brook, Stony Brook, and Jordan Brook (figs. 1 and 2). The watersheds encompass parts of the towns of Lyme, Old Lyme, East Lyme, Montville, and Waterford (fig. 2). Two locations in each watershed were selected for sample collection and water-quality monitoring, including one upstream and one downstream from I-95 (fig. 3). Streamgages are located at the downstream sites. The watersheds vary in size from 1.86 to $5.98 \mathrm{mi}^{2}$ and include both commercial and undeveloped areas; developed land ranges from 9.4 percent at the Four Mile River watershed to 30.5 percent at the Jordan Brook watershed (table 1). Data on highway drainage, which were acquired from ConnDOT, were considered in the delineation of the watershed boundaries. Data on 2002 land-use and land-cover characteristics were determined from LANDSAT Thematic Mapper (TM) data, retrieved from the Center for Land use Education And Research (CLEAR) website (University of Connecticut, 2009). Data on land-use and land-cover characteristics also were determined from TM images created for the National Land Cover Dataset (NLCD; U.S. Environmental Protection Agency, 2001).

The study area is underlain by surficial deposits, including Pleistocene glacial stratified deposits, glacial till, and Holocene alluvial deposits, which occur primarily in stream channels (table 2). These deposits are underlain by crystalline bedrock. Effective recharge to the glacial stratified deposits (Melvin and Bingham, 1991) and groundwater storage and flow within these deposits is much larger than in till deposits. There is a 10-percent increase in coarse-grained surficial deposits (8.0 to 18.3 percent of watershed area) between the Stony Brook upstream and downstream sites; therefore, base flow is likely an important contribution to streamflow downstream from I-95 in this watershed.

\section{Sources of Dissolved Constituents to Streams and Groundwater}

The primary water-quality constituents of interest in this study are dissolved $\mathrm{Cl}, \mathrm{Na}$, and calcium $(\mathrm{Ca})$ because these are the major dissolved ions in meltwater from road deicers applied to highways. These ions are derived from ionic compounds or "salts" such as $\mathrm{NaCl}, \mathrm{CaCl}_{2}$, and magnesium chloride $\left(\mathrm{MgCl}_{2}\right)$ that dissolve easily in water. Other anthropogenic sources of $\mathrm{Cl}$ include discharge from drinkingwater and wastewater-treatment facilities or septic systems, leachate from landfills, fertilizers, and petroleum or chemical spills. Natural sources of salts to freshwater resources include (1) atmospheric deposition; (2) the natural weathering of bedrock, surficial materials, and soils; (3) seawater; and (4) geologic deposits containing halite or saline groundwater (brines). Halite and brines are not present in geologic deposits in this area and, therefore, are not likely to affect stream chemistry in this study.

Atmospheric deposition generally transmits salts from both anthropogenic and natural sources to watersheds and groundwater. Atmospheric deposition of major ions is more concentrated in coastal areas than in inland areas (Gay and Melching, 1995). Cl load in precipitation can be a substantial part of the total $\mathrm{Cl}$ load in relatively undeveloped areas, particularly in coastal areas (Mullaney and others, 2009; National Atmospheric Deposition Program, 2009) (fig. 4). The $\mathrm{Cl}$ load from atmospheric deposition was estimated by using the monthly median concentrations and the amount of rainfall at three National Atmospheric Deposition Program (NADP) stations (fig. 1), then calculating the $\mathrm{Cl}$ mass per unit area. Estimated $\mathrm{Cl}$ loads ranged from 0.0012 (ton $/ \mathrm{d}) / \mathrm{mi}^{2}$ at an inland site in Abington, Conn., to 0.11 (ton/d) $/ \mathrm{mi}^{2}$ at a coastal site in Cedar Beach, N.Y., during November 2008 to September 2009. The Cedar Beach, N.Y., station is located on an island peninsula within $200 \mathrm{ft}$ of saltwater and is strongly affected by sea spray; therefore, the value for Cedar Beach probably is an overestimate of atmospheric deposition for watersheds in this study (table 3). Chloride estimates for the station at Lexington, Mass., is probably most representative of the study area. The estimates of $\mathrm{Cl}$ load from the atmospheric deposition, based on the range of monthly concentrations at the NADP stations (fig. 1), vary from 0.1 ton per day (ton/d) for the Stony Brook downstream site watershed to 3.1 ton/d for the Four Mile River downstream site watershed (table 3 ).

The primary road deicers used by the ConnDOT include $\mathrm{NaCl}$ (both in the brine and halite form) and $\mathrm{CaCl}_{2}$; those used by the towns include $\mathrm{NaCl}$ (halite) and a product that contains $\mathrm{MgCl}_{2}$ together with distillers condensed solubles, as described in the section "Road Deicing Chemicals and their Application in the Study Areas." Stormwater runoff from I-95 is the primary focus of this study, but there are other contributions to streamflow in each watershed, including stormwater runoff from other roadways and impervious surfaces, interflow, and the groundwater component (base flow). Sources of major ions in base flow include groundwater 


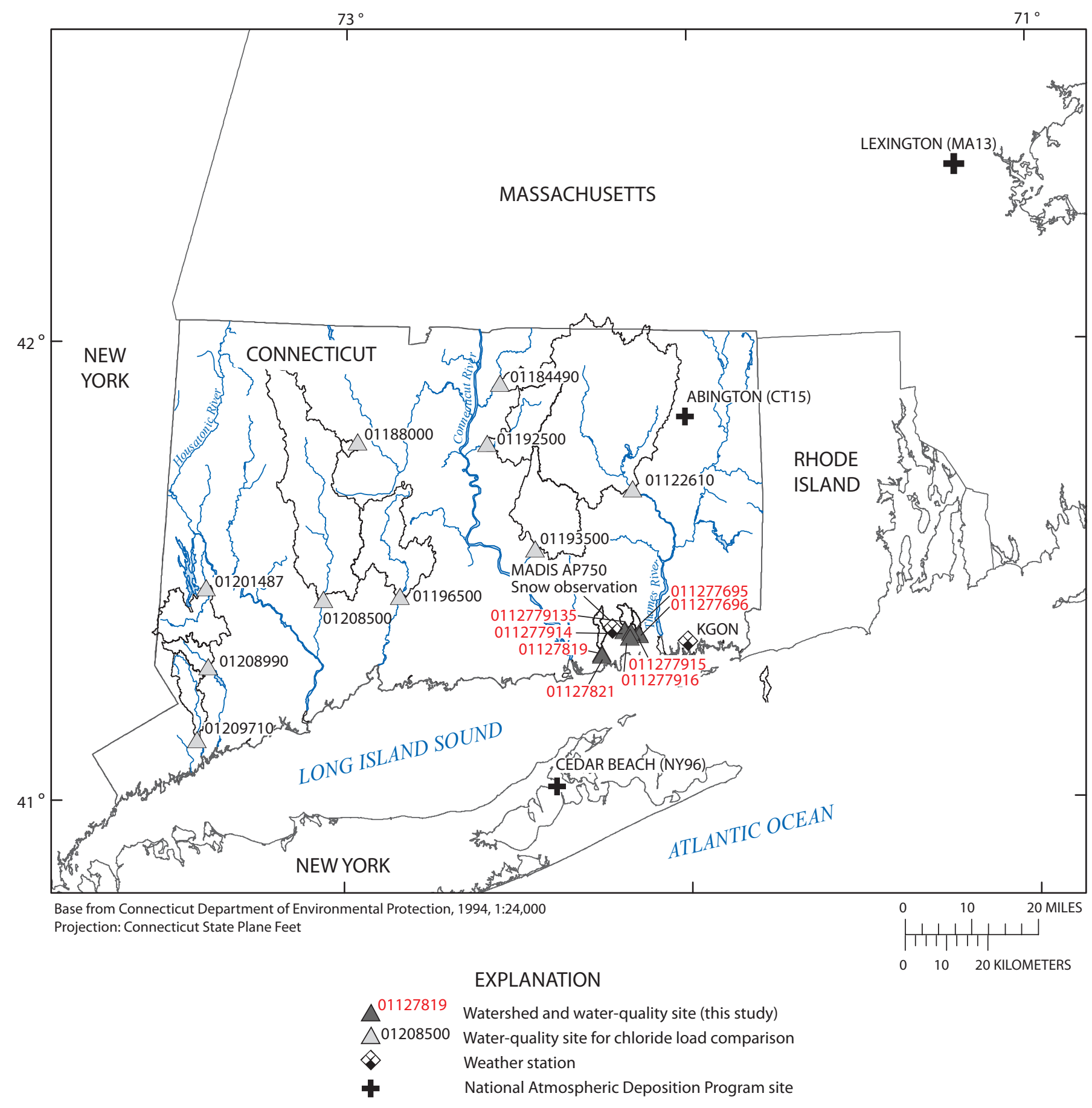

Figure 1. Location of water-quality monitoring sites for this study, and sites on other rivers in Connecticut, and several weather stations, including the Groton-New London airport weather station, a Snow Observation weather station, and three National Atmospheric Deposition Program sites. 


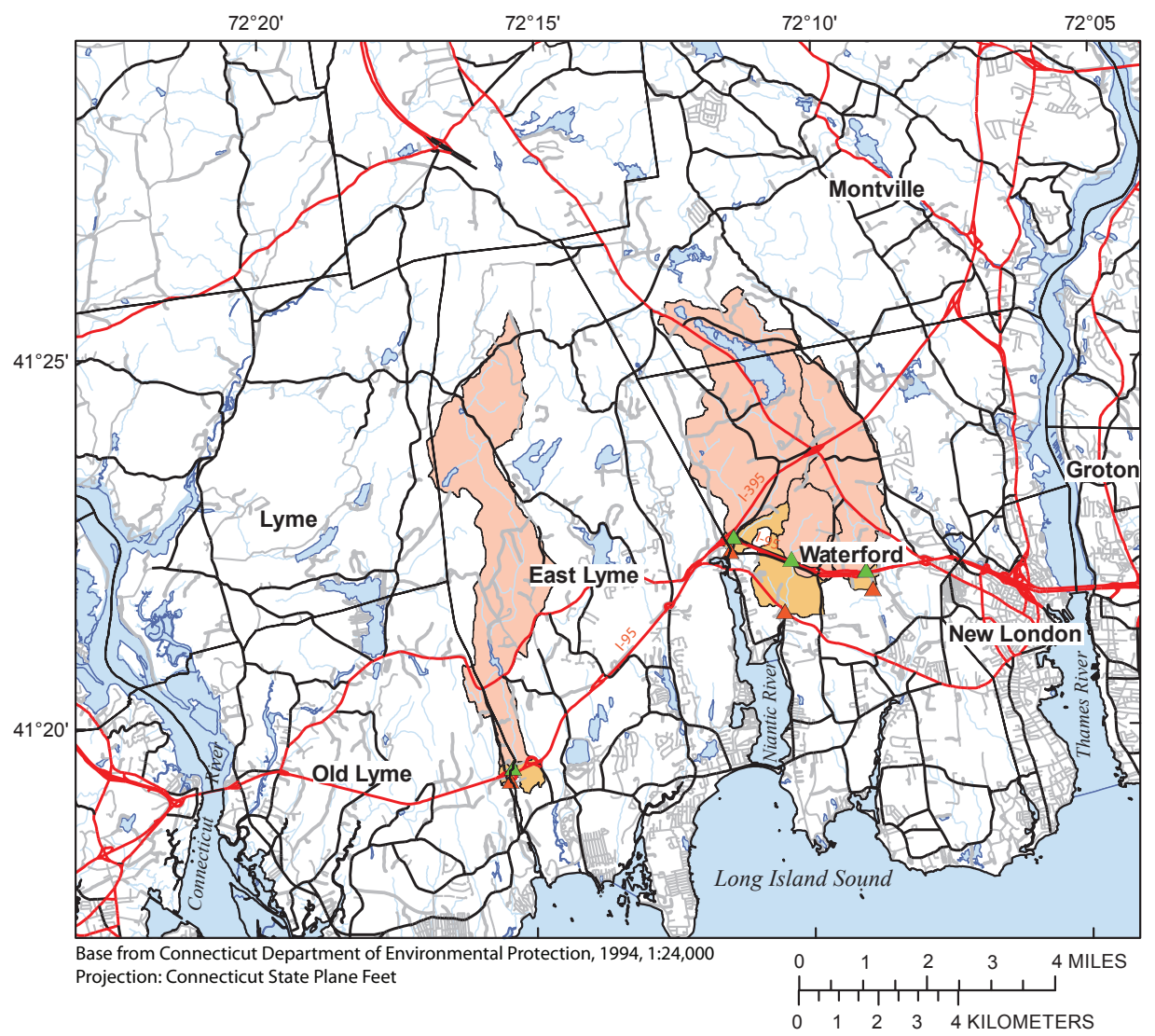

EXPLANATION

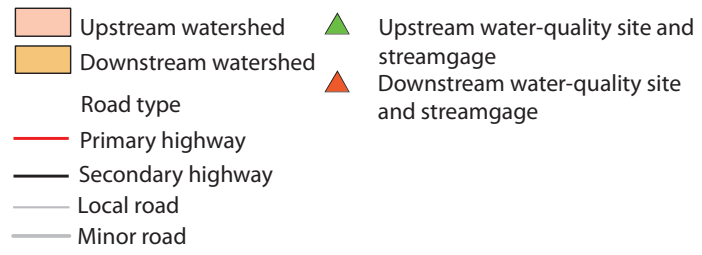

Figure 2. Upstream and downstream water-quality monitoring sites and downstream streamgages on the four selected streams and their watersheds along the Interstate 95 corridor study area, southeastern Connecticut. 


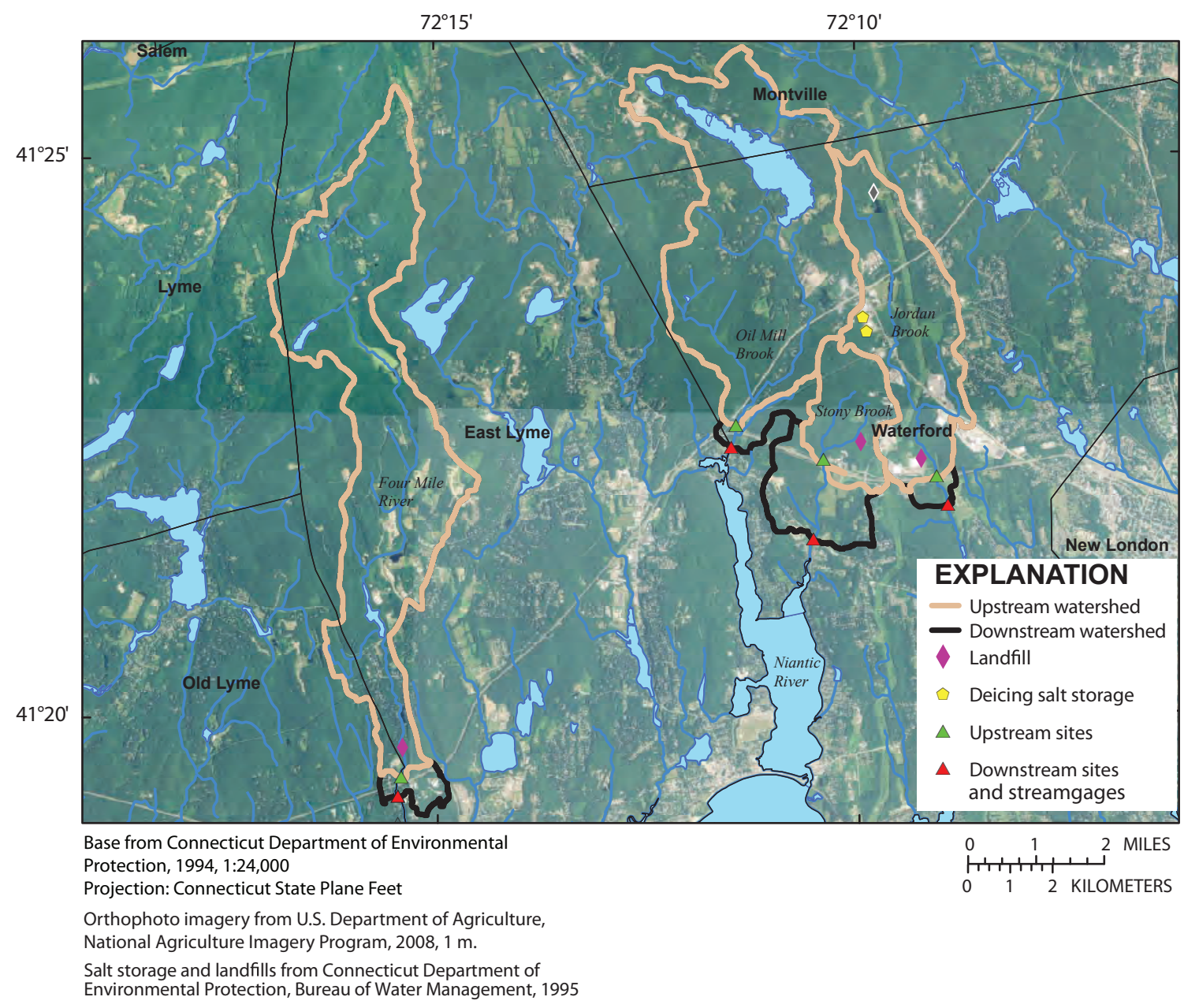

Figure 3. Water-quality monitoring sites and downstream streamgages, watershed boundaries, and deicing salt storage and landfill locations in the study areas, southeastern Connecticut.

recharge, road deicers and deicer storage locations, septic-tank drainfields, landfills, fertilizers, and petroleum or chemical spills, as well as aquifer weathering. Potential point sources of $\mathrm{Cl}$ in each watershed were determined from a 1:50,000-scale data layer that includes point locations digitized from "Leachate and Wastewater Discharge Source" maps compiled by the CTDEP and point locations digitized on-screen from CTDEP sources (Connecticut Department of Environmental Protection, 1995).

\section{Road Deicing Chemicals and their Application in the Study Areas}

Road deicing chemicals are a primary source of $\mathrm{Cl}$ and other constituents to water resources near highways or other impervious surfaces in the northern United States (Bubeck and others, 1971; Mullaney and others, 2009; Wulkowicz and Saleem, 1974). Road deicers include $\mathrm{NaCl}, \mathrm{CaCl}_{2}, \mathrm{MgCl}_{2}$, and other mixtures that can include distillers condensed solubles ${ }^{1}$. The use of $\mathrm{NaCl}$ in the United States has increased from 42.9 million tons in 1975 to nearly 58.5 million tons in 2005 (Kostick and others, 2007). The application of $\mathrm{NaCl}$ to roads is now the largest use of salt and represents 39.5 percent of the end use of salt in the United States (Kostick and others, 2007).

During the past decade, deicing of state roads throughout New England and other northern states has changed (2000-09) from simply plowing and salting and sanding to include pretreating by spraying liquids that prevent snow and ice from bonding with the road (anti-icing) and using less sand. Under field conditions, $\mathrm{NaCl}$ lowers the freezing point of

\footnotetext{
${ }^{1}$ Fermentation by-products, which include spent yeast cells and other nutrients, that remain after corn grain has been fermented to produce ethanol, known in the food industry as "corn syrup."
} 


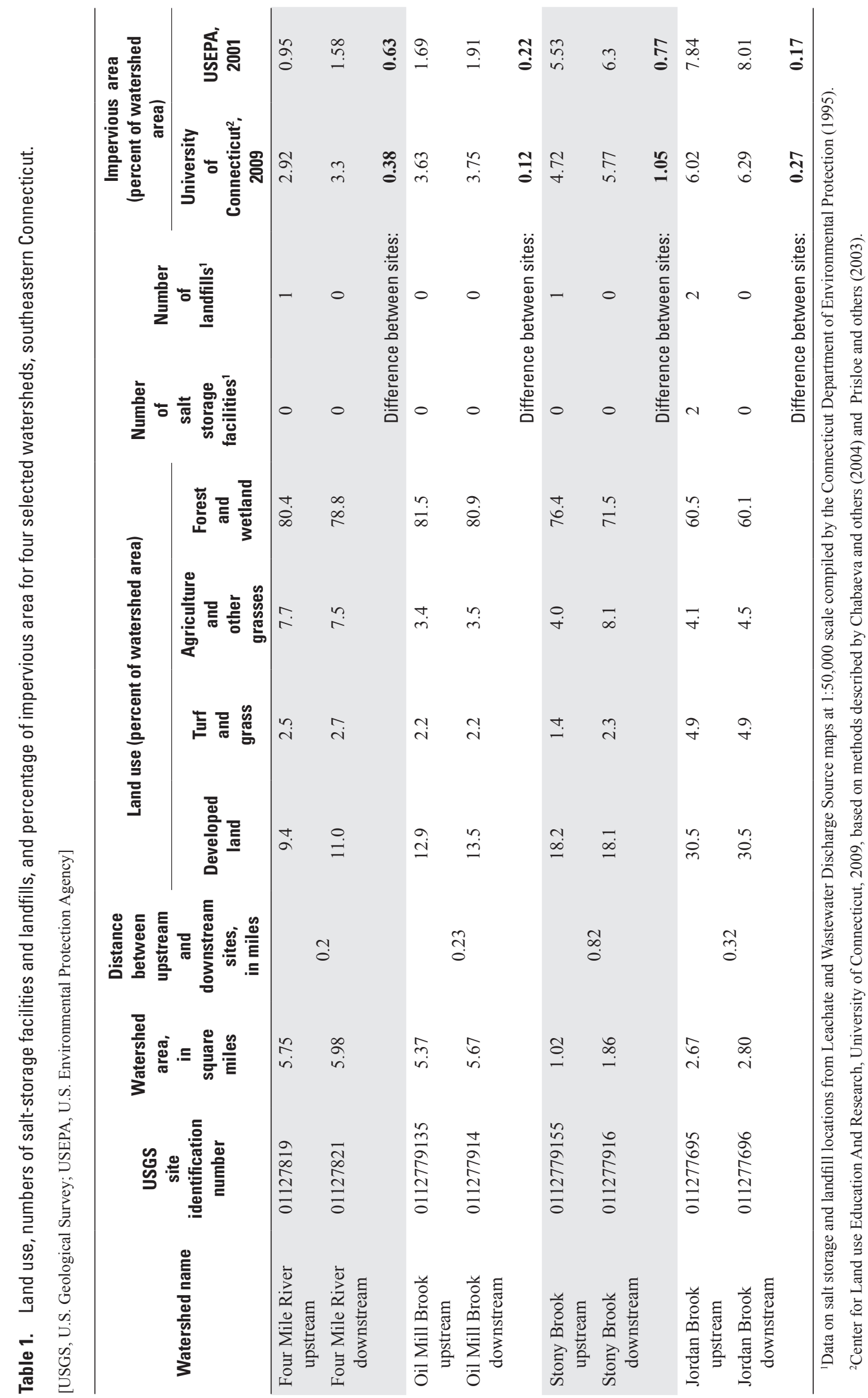


Table 2. Classification of surficial materials for watersheds above each monitoring site in the study area, southeastern Connecticut.

[Data from Stone and others, 1992. USGS, U.S. Geological Survey; us, upstream; ds, downstream]

\begin{tabular}{|c|c|c|c|c|c|c|}
\hline \multirow{2}{*}{ Watershed name } & \multirow{2}{*}{$\begin{array}{c}\text { USGS } \\
\text { site identification } \\
\text { number }\end{array}$} & \multicolumn{5}{|c|}{ Surficial material, in percent of watershed area } \\
\hline & & Coarse grained & Swamp or fines & Till & Thick till & Water \\
\hline Four Mile River us & 01127819 & 16.3 & 1.6 & 73.7 & 7.5 & 0.9 \\
\hline Four Mile River ds & 01127821 & 16.2 & 1.5 & 73.3 & 8.1 & 0.9 \\
\hline Oil Mill Brook us & 0112779135 & 13.3 & 1.6 & 71.5 & 4.8 & 8.8 \\
\hline Oil Mill Brook ds & 011277914 & 18.7 & 1.5 & 71.7 & 4.5 & 8.4 \\
\hline Stony Brook us & 0112779155 & 8.0 & 14.8 & 77.2 & 0.0 & 0.0 \\
\hline Stony Brook ds & 011277916 & 18.3 & 7.5 & 74.2 & 0.0 & 0.0 \\
\hline Jordan Brook us & 011277695 & 17.9 & 3.1 & 74.7 & 4.3 & 0.0 \\
\hline Jordan Brook ds & 011277696 & 18.7 & 3.0 & 74.2 & 4.1 & 0.0 \\
\hline
\end{tabular}

water to $-9^{\circ} \mathrm{C}$; other salts, such as $\mathrm{CaCl}_{2}$, depress the freezing point even lower (to $-29^{\circ} \mathrm{C}$ ), but these are more expensive (Connecticut Department of Transportation, 2009). NaCl brine, therefore, is generally applied to state bridges, ramps, overpasses, and some roads before snow or ice events.

ConnDOT initiated a new snow and ice removal program beginning in the 2006-07 winter season (Connecticut Department of Transportation, 2009). ConnDOT crews generally avoid using sand on roadways because it provides only temporary traction, fouls waterways and the air, clogs drains, and is costly to clean up. The primary purpose of the new program is to reduce the use of sand and improve winter driving conditions by (1) pretreating pavements with $\mathrm{NaCl}$ brine, thus preventing bonding of snow or ice, and (2) using liquid $\mathrm{CaCl}_{2}$ as a wetting agent for rock salt (halite), which is applied during snow or ice events, to lower the freezing point, to reduce bounce and scatter, and to accelerate the melting time.

ConnDOT uses a 23-percent $\mathrm{NaCl}$ brine solution for anti-icing at a rate of about 30 gal per lane mile. Larger rates (40 gal per lane mile) of the $\mathrm{NaCl}$ brine solution are applied at pavement temperatures below $-1^{\circ} \mathrm{C}$, but none is applied below $-5.5^{\circ} \mathrm{C}$ because it is ineffective at colder temperatures. The brine solution is applied by a tanker truck using spray bars with nozzles that are spaced about 10 in. apart. After application of the brine solution, the water evaporates as 2 -in. strips that melt frozen precipitation on contact. The program also calls for the pretreating of bridges and selected roadways with salt brine up to 5 days prior to an anticipated precipitation event.
$\mathrm{CaCl}_{2}$ in liquid form (about 32 percent by weight) has been used on Connecticut state roads since the 2006-07 winter. It is sprayed onto halite rock salt in the spreader chute on plows and other snow-removal equipment. The $\mathrm{CaCl}_{2}$ brinehalite combination melts snow or ice faster during application than using only halite and sand. The typical mixing rate is 10 gal of liquid $\mathrm{CaCl}_{2}$ per ton of rock salt, but the rates are varied depending on such factors as temperature, humidity, the type and timing of storms, and traffic conditions (Connecticut Department of Transportation, 2009). In some situations where ice has already formed, liquid ice-control chemicals $\left(\mathrm{CaCl}_{2}\right.$ or $\mathrm{NaCl}$ brine) are applied directly to the pavement.

During this study, ConnDOT maintained records of deicers applied to I-95 along specific lengths of roads. These records include the length and type of state-operated roads within (1) the Four Mile River watershed and (2) the combined watersheds of Oil Mill Brook, Stony Brook, and Jordan Brook (table 4); the dates and times of application; and the quantity of deicers and sand applied over a given spreader route (table 5). All road salt applied to I-95 meets standards that specify chemical purity. $\mathrm{NaCl}$ conforms to the standard ASTM D632-84, which specifies that all samples tested must be at a minimum of 95 -percent pure $\mathrm{NaCl}$, and all $\mathrm{CaCl}_{2}$ must be a minimum of 90 -percent pure as specified by the standard ASTM D98-93. Typical spreading rates from trucks with calibrated spreaders are about $300 \mathrm{lb}$ per lane-mile, +/- 20 percent (Connecticut Department of Transportation, 2009). The total amount of deicers applied to the highway varied from storm to storm and year to year (table 5). The deicers applied to I-95 and other state roads for the 2008-09 winter season were categorized by (1) storms, which refers 


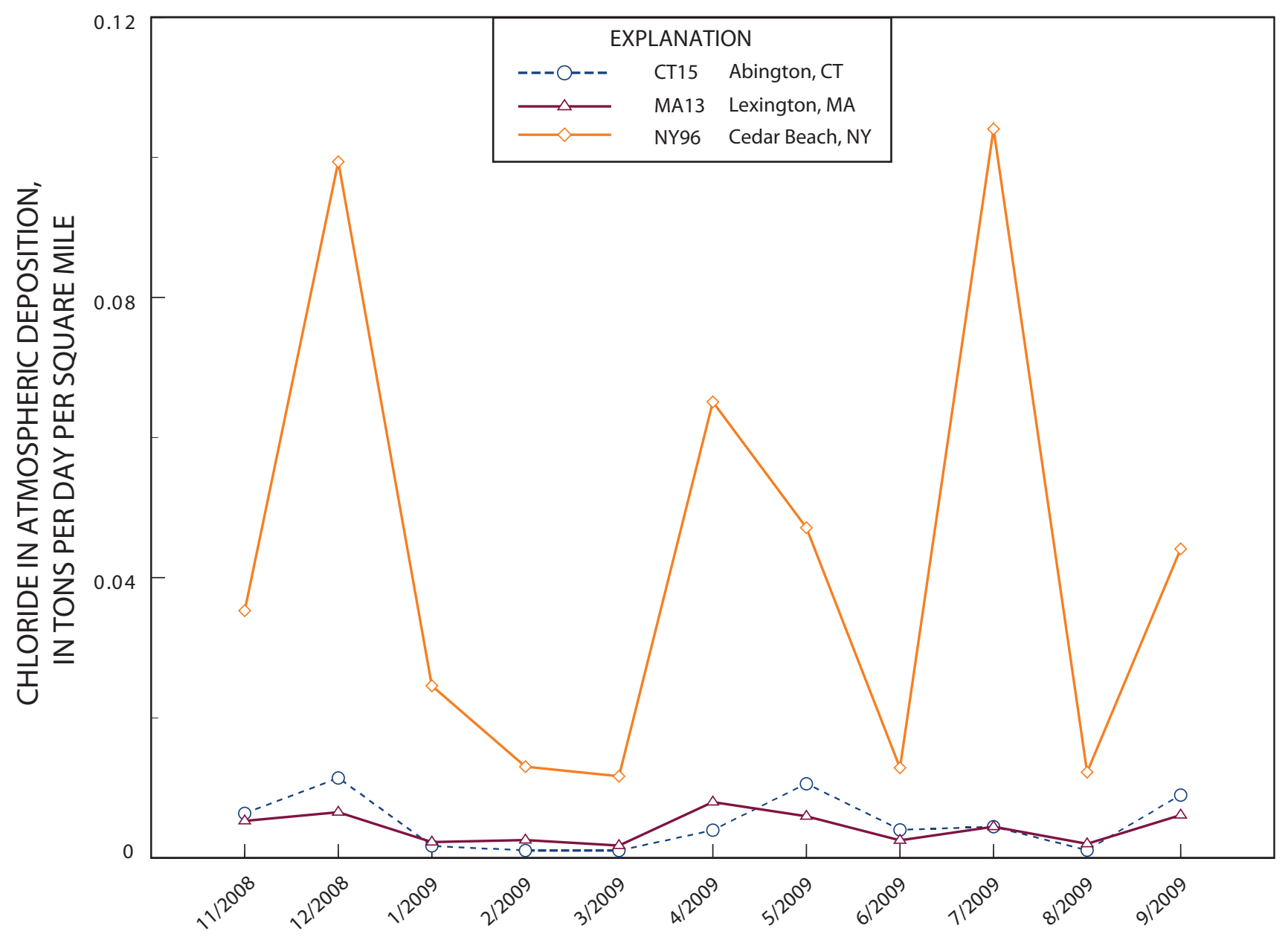

MONTH AND YEAR

Figure 4. Estimated monthly median chloride loads in atmospheric deposition based on three National Atmospheric Deposition Program stations, November 2008 - September 2009. Data are from National Atmospheric Deposition Program, 2009. (Locations of sites are shown in fig. 1.)

to snow or ice storm events, and (2) activities, such as icy conditions or drifting snow, which generally require shorter periods of deicing (table 5; Connecticut Department of Transportation, 2009). The deicers and sand applied to these areas during the 2006-07 and 2007-08 winter seasons are summarized in table 5.

The town of Old Lyme used $\mathrm{NaCl}$ (halite) and sand to treat snow and ice on town roads during the 2008-09 winter season and applied 1.6 tons of $\mathrm{Cl}$ per road mile to roads within the Four Mile River watershed (E. Adanti, Town of Old Lyme, oral commun., 2009). The other towns in the study_East Lyme, Waterford, and Montville — used a deicing product called Ice B' Gone ${ }^{\circledR}$ that contains $\mathrm{MgCl}_{2}$ together with distillers condensed solubles (table 6). The mixture is described as having a synergistic melting effect that results in a melting temperature of $-31^{\circ} \mathrm{C}$ (Sears Ecological Applications Co., LLC, 2009). The town of East Lyme applied an estimated 5.6 tons of $\mathrm{Cl}$ per road mile to roads within the Four Mile River watershed during the 2008-09 winter season in the form of $\mathrm{NaCl}$ (halite) and Ice B' Gone ${ }^{\circledR}$ (M. Giamattasio, Town of East Lyme, oral commun., 2009). The town of Montville also used a combination of $\mathrm{NaCl}$ (halite) and Ice B' Gone ${ }^{\circledR}$ and applied about 21.1 tons per road mile to roads within the Oil Mill Brook watershed during the 2008-09 winter season (D. Bordeau, Town of Montville, oral commun., 2009). The town of Waterford, which used only Ice B' Gone ${ }^{\circledR}$ during the 2008-09 winter season, applied about 8.4 tons of $\mathrm{Cl}$ per road mile to roads within the Oil Mill Brook, Stony Brook, and Jordan Brook watersheds (R. Cusano, Town of Waterford, oral commun., 2009). 
Table 3. Estimated atmospheric deposition yields and loads of chloride for the four selected watersheds in southeastern Connecticut. Loads were computed from National Atmospheric Deposition Program stations in Abington, Conn., Lexington, Mass., and Cedar Beach, N.Y., November 2008-September 2009.

[Data from National Atmospheric Deposition Program (NADP), 2009. Location of stations shown in fig. 1.]

\begin{tabular}{|c|c|c|c|c|c|c|c|c|}
\hline \multirow[t]{2}{*}{$\begin{array}{l}\text { NADP } \\
\text { station }\end{array}$} & \multirow[t]{2}{*}{$\begin{array}{c}\text { NADP } \\
\text { station location }\end{array}$} & \multicolumn{3}{|c|}{$\begin{array}{l}\text { Atmospheric deposition yields, } \\
\text { in tons per day per square mile }\end{array}$} & \multicolumn{4}{|c|}{$\begin{array}{l}\text { Atmospheric deposition loads, } \\
\text { in tons per day } \\
\text { (November } 2008 \text { to September 2009) }\end{array}$} \\
\hline & & $\begin{array}{l}\text { Lower } \\
\text { range }\end{array}$ & $\begin{array}{l}\text { Upper } \\
\text { range }\end{array}$ & Median $^{1}$ & $\begin{array}{l}\text { Four Mile } \\
\text { River }\end{array}$ & $\begin{array}{l}\text { Oil Mill } \\
\text { Brook }\end{array}$ & $\begin{array}{l}\text { Stony } \\
\text { Brook }\end{array}$ & $\begin{array}{c}\text { Jordan } \\
\text { Brook }\end{array}$ \\
\hline CT15 & Abington, CT & 0.001 & 0.012 & 0.005 & 0.36 & 0.34 & 0.11 & 0.17 \\
\hline MA13 & Lexington, MA & 0.002 & 0.009 & 0.005 & 0.31 & 0.30 & 0.10 & 0.15 \\
\hline NY96 & Cedar Beach, NY & 0.013 & 0.11 & 0.040 & 3.1 & 2.9 & 0.96 & 1.4 \\
\hline
\end{tabular}

${ }^{1}$ Median values were used to compute atmospheric deposition for study watersheds.

\section{Methods of Data Collection and Analysis}

Data were collected during the interim study period (as early as November 1,2008 , to September 30,2009 ) using methods described below to assess weather information, water quality, stream stage, and streamflow for the four selected streams. All water-quality, stream-stage, and streamflow data are stored in the USGS National Water Information System (NWIS) database.

\section{Site Selection}

Approximately 17 streams between the Connecticut River and the Thames River that are crossed by I-95 were initially considered as locations for potential monitoring sites. Site selection involved assessment of available geographic information system (GIS) data and streamflow characteristics of all the watersheds upstream from and encompassing parts of I-95. Four streams between the Connecticut River and the Thames River (fig. 1) - Four Mile River, Oil Mill Brook, Stony Brook, and Jordan Brook - were selected for study on the basis of the percentage of land-use types, percentage of impervious surfaces, road types and density, presence of coarse glacial stratified deposits, suitability for streamflow and water-quality monitoring, site accessibility, representativeness and transferability, and the absence of estuarine or brackish waters.

\section{Weather Data}

Hourly measurements of air temperature and precipitation for the study period were obtained from continuous temperature and precipitation data collected by the National Weather Service at the Groton-New London airport weather station (KGON; fig. 1) as part of the Meteorological Assimilation Data Ingest System (MADIS). The data were accessed through Weather Underground (http://www. wunderground.com).

Another branch of the National Weather Service, the National Operational Hydrologic Remote Sensing Center, assembles daily ground-based, airborne, and satellite snow observations for the conterminous United States (National Operational Hydrologic Remote Sensing Center, 2005). These data are used together with estimates of snowpack characteristics generated by a snow model to generate the operational, daily NOAA National Snow Analysis for the United States, for which estimates are made for snow depth, snow-water equivalent, and snow melt. The snow observation station (MADIS AP750) nearest the study area is located at $\mathrm{N} 41.36733^{\circ}, \mathrm{W} 72.216^{\circ}$, at an altitude of $72 \mathrm{ft}$ above NAVD 88 (fig. 1).

\section{Streamflow}

Stream stage and streamflow were measured at four sites downstream from I-95 on Four Mile River, Oil Mill Brook, Stony Brook, and Jordan Brook (fig. 3) and used for computations of $\mathrm{Cl}$ loads in highway stormwater runoff. Stream stage was recorded at 5-minute intervals with pressure transducers and data loggers, and streamflow measurements were made periodically at these sites. These data were used to develop a rating curve to convert stage measurements into streamflow. All streamflow records were computed in accordance with standard USGS protocols for computation of streamflow records as described by Rantz and others (1982).

\section{Water Quality}

Water-quality data were collected at sites upstream and downstream from I-95 on the Four Mile River, Oil Mill Brook, Stony Brook, and Jordan Brook to monitor $\mathrm{Cl}$ concentrations and to evaluate the loads at downstream sites. Water quality was assessed using continuous monitors and periodic grab samples collected during base flow and winter storms. 
Table 4. Description of two areas of Interstate 95 in which the deicing chemicals were applied to state-operated roads within areas of (1) the Four Mile River watershed and (2) the combined Oil Mill Brook, Stony Brook, and Jordan Brook watersheds, southeastern Connecticut.

[Data from K. Carifa, Connecticut Department of Transportation, written commun., 2009; mi, mile; ft, feet; N/B, northbound; S/B, southbound]

\begin{tabular}{|c|c|c|c|}
\hline (1) Four Mile River watershed study area & $\begin{array}{c}\text { Distance, } \\
\text { in miles }\end{array}$ & $\begin{array}{l}\text { (2) Oil Mill-Stony Brook-Jordan Brook watersheds } \\
\text { study area: }\end{array}$ & $\begin{array}{c}\text { Distance, } \\
\text { in miles }\end{array}$ \\
\hline \multicolumn{2}{|l|}{ I-95 N/B (Old Lyme/East Lym) Mile Marker 83 to 84} & \multicolumn{2}{|l|}{ I-95 N/B (Waterford) Mile Marker 88 to 92} \\
\hline Two 12-ft lanes w/shoulder & 1 & Two 12-inch lanes with shoulder & 4 \\
\hline N/B Exit 71 off ramp & 0.24 & On ramp from Oil Mill & 0.11 \\
\hline N/B Exit 71 on ramp & 0.30 & Exit 81 Cross Roads off & 0.09 \\
\hline \multirow[t]{2}{*}{ N/B Exit 72 to Rocky Neck Connector } & \multirow[t]{2}{*}{0.20} & Exit 81 Cross Roads on & 0.15 \\
\hline & & Scale House exit ramp & 0.18 \\
\hline \multicolumn{2}{|l|}{ I-95 N/B (East Lyme/Old Lyme) Mile Marker 84 to 83} & Scale House on ramp & 0.18 \\
\hline Two 12-ft lanes with shoulder & 1 & Exit 82 off ramp to 85 & 0.19 \\
\hline S/B Exit 72 to Rocky Neck Connector & 0 & Exit 82 on ramp from 85 & 0.06 \\
\hline S/B on ramp from Rocky Neck Connector & 0 & & \\
\hline S/B Exit 71 off ramp & 0 & \multicolumn{2}{|l|}{ I-95 S/B (Waterford) -Mile marker 92 to 88} \\
\hline \multirow[t]{2}{*}{ S/B Exit 71 on ramp } & \multirow[t]{2}{*}{0} & Two 12-ft lanes with shoulder lane & 4 \\
\hline & & Exit 82 off ramp to 85 & 0.13 \\
\hline \multicolumn{2}{|l|}{ Route $1 \mathrm{~N} \&$ S (0ld Lyme/East Lyme) Mile marker 87 to 90} & Exit 82 on ramp to 85 & 0.14 \\
\hline \multirow[t]{2}{*}{ Two 12-ft lanes with approximately $4 \mathrm{ft}$ shoulder } & \multirow{2}{*}{3} & Scale House exit ramp & 0.18 \\
\hline & & Scale House on ramp & 0.18 \\
\hline Service Road 432 East Lyme & & Exit 81 Cross Roads off & 0.07 \\
\hline Two 12-ft lanes, no shoulder & 0.54 & Exit 81 Cross Roads on & 0.16 \\
\hline Total 2 lane mi: & 5.5 & Off ramp to Oil Mill & 0.12 \\
\hline \multirow[t]{15}{*}{ Total ramp mileage: } & 1.7 & & \\
\hline & & \multicolumn{2}{|l|}{ I-395 N/B (Waterford) Mile Marker 1 to 3} \\
\hline & & Two 12-ft lanes with shoulder & 3 \\
\hline & & Exit 77 N/B off ramp (Route 85) & 0.22 \\
\hline & & Exit 77 N/B on ramp (Route 85) & 0.18 \\
\hline & & \multicolumn{2}{|l|}{ I-395 S/B (Waterford) Mile Marker 3 to 1} \\
\hline & & Two $12 \mathrm{ft}$ lanes with shoulder & 3 \\
\hline & & exit 77S/B off ramp (Route 85) & 0.18 \\
\hline & & exit 77S/B on ramp (Route 85) & 0.19 \\
\hline & & \multicolumn{2}{|l|}{ Route 85 N/B (Waterford/Montville) Marker 1 to 7} \\
\hline & & Two 12-ft lanes with shoulder & 6 \\
\hline & & \multicolumn{2}{|l|}{ Route $1 \mathrm{~N} \& S$} \\
\hline & & Route 1 N/B (Waterford) Marker 93 to 94 & 0.97 \\
\hline & & Total 2 lane mi & 21 \\
\hline & & Total ramp mileage: & 2.7 \\
\hline
\end{tabular}




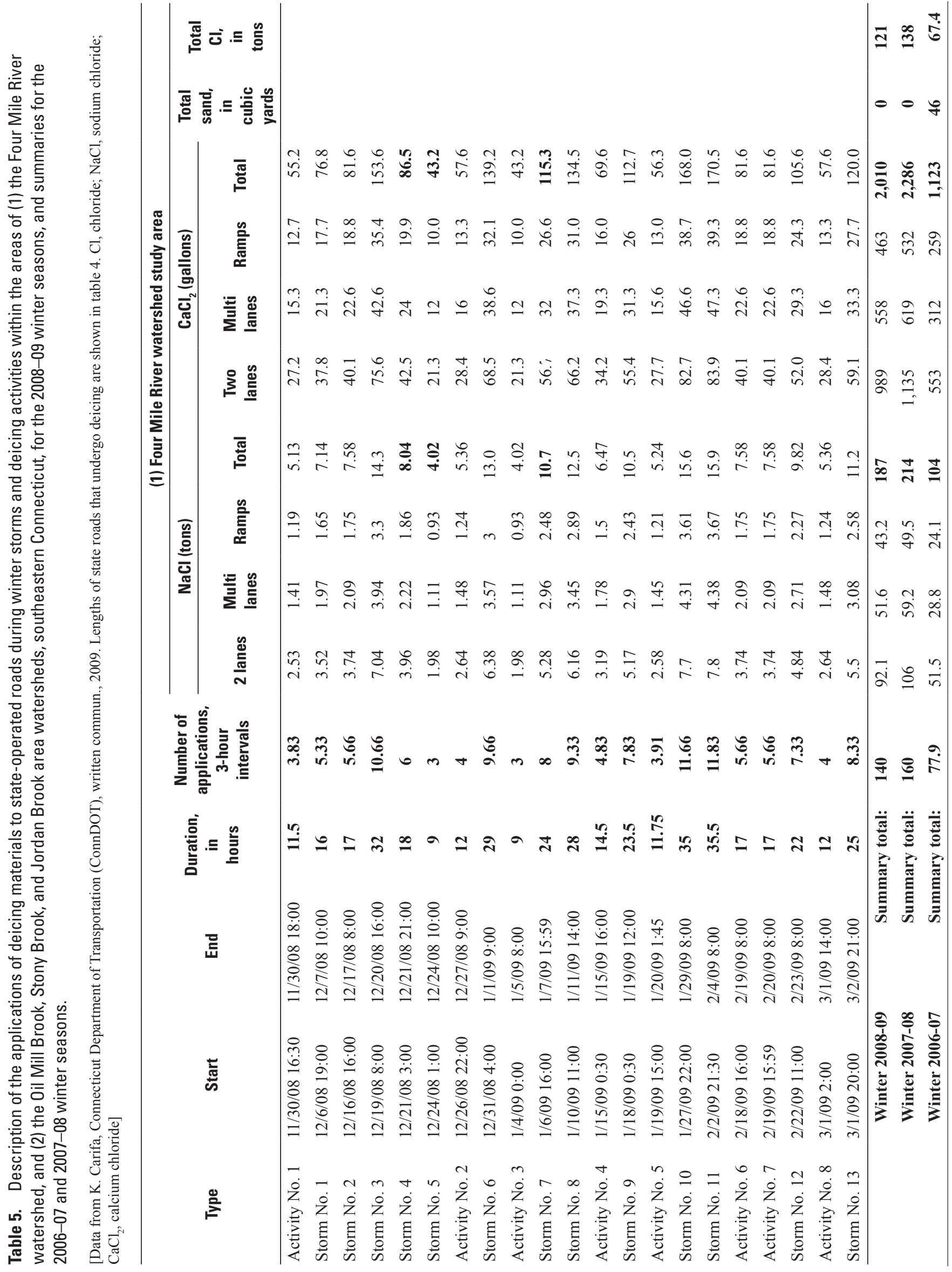




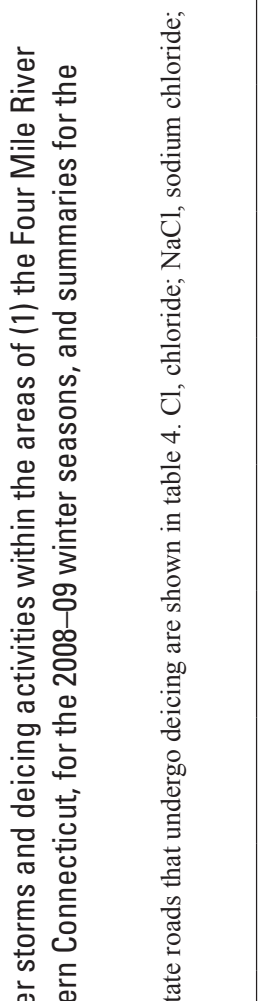

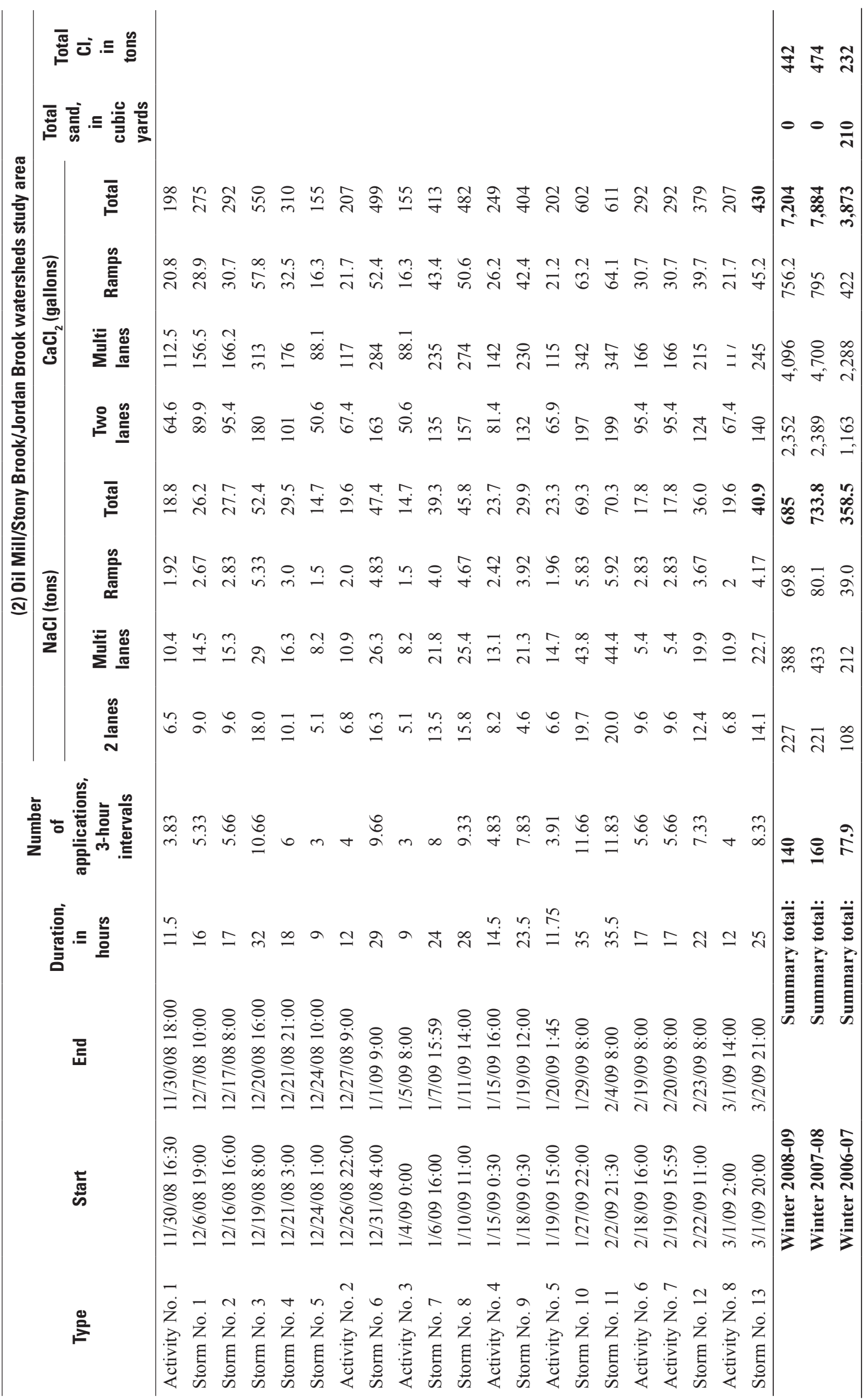




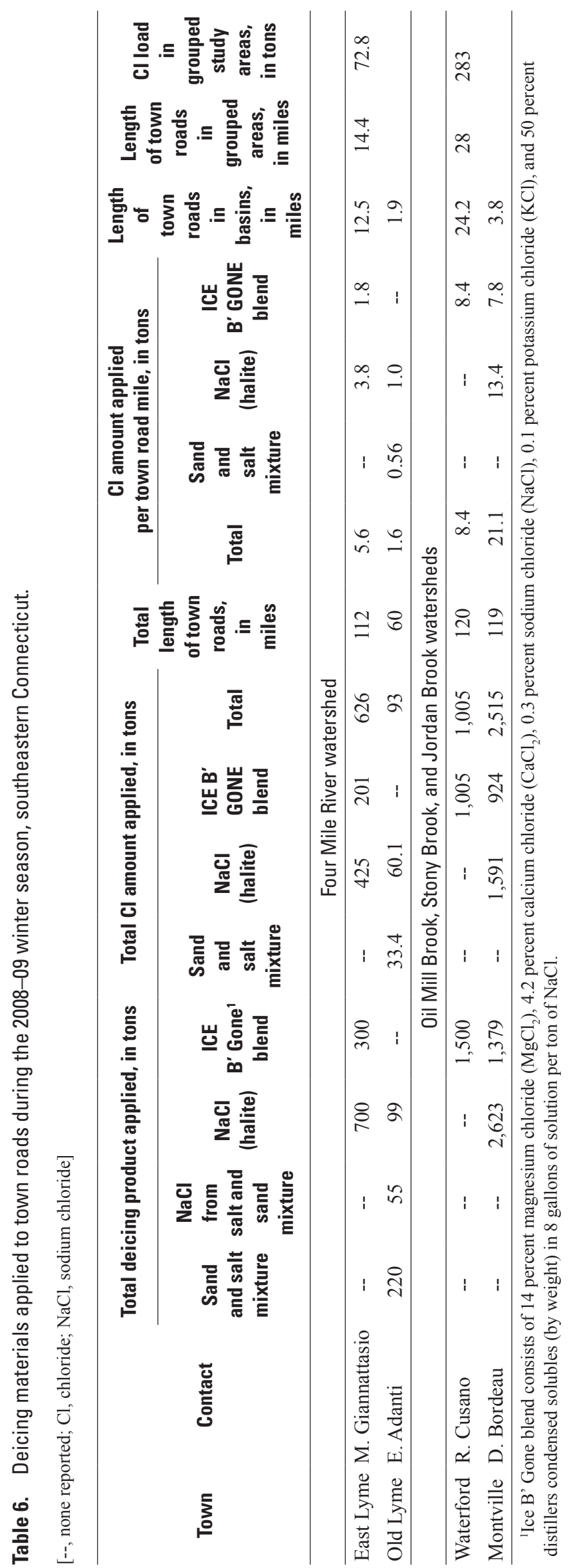




\section{Continuous Monitoring}

Continuous monitoring of water quality at each sampling site was accomplished using a water-quality monitoring instrument for measurement of temperature, specific conductance, and $\mathrm{pH}$ at 10 -minute intervals. All procedures relating to water-quality monitors (calibration, maintenance, record computation, storage, and archiving) are described by Wagner and others (2006).

\section{Water-Quality Sampling and Laboratory Analysis}

Water-quality grab samples were collected

(1) approximately monthly during routine conditions,

(2) during base-flow conditions, and (3) during winter runoff events, such as winter storms or warm periods in which snow or ice melts. Field characteristics, which include water temperature, $\mathrm{pH}$, and specific conductance, were measured during sample collection in accordance with USGS procedures described by Wilde (2004; 2005). Grab samples generally were analyzed for $\mathrm{Cl}$ concentrations only, and samples collected on August 19, 2009, during base-flow conditions were analyzed for major ions. All water samples collected were analyzed by the USGS National Water-Quality Laboratory (NWQL) in Denver, Colo., using the methodology described in Fishman and Friedman (1989).

\section{Quality Assurance}

Field sensors were regularly cleaned and calibrated with standard solutions and checked periodically with independent field and laboratory sensors. Continuous stage data and water-quality data were checked and corrected or censored for interruptions or shifts caused by debris, ice, or low-flow conditions. Quality-control procedures for the collection of continuous specific-conductance data followed procedures described in Wagner and others (2006).

Field quality-control procedures included the collection and analysis of replicate and blank samples. Fieldblank samples provided information on bias or possible contamination during sample collection, processing, or analysis. Analytical results from the field-blank samples showed that concentrations of constituents were less than the reporting level. Analysis of replicate samples provided information on the variability of analytical results caused by sample collection, processing, and analysis. Analytical methods used in the laboratory for analysis of constituent concentrations were reported to be accurate within 3 to 12 percent for major ions, depending on the ionic concentration and the analytical method used (Fishman and Friedman, 1989). The charge balances for major ion analyses were all within $+/-3$ percent.

\section{Data Analysis}

Data analysis included graphical plotting of concentrations of water-quality constituents, multiplecomparison tests, and statistical analyses of the relations between ancillary variables and $\mathrm{Cl}$ concentrations and yields in surface water.

\section{Estimation of Chloride Concentrations}

$\mathrm{Cl}$ concentrations were estimated using regression models that described the relation among measured $\mathrm{Cl}$ concentrations, specific conductance, and instantaneous streamflow. Grab samples collected manually at each of the sites upstream and downstream from I-95 from November 2008 to January 2010 and analyzed for $\mathrm{Cl}$ concentrations provided the "measured" $\mathrm{Cl}$ concentrations used in the regression models specific to each site (appendix 1).

The resulting multiple linear regression models were then used to predict daily mean $\mathrm{Cl}$ concentrations on the basis of daily mean values of specific conductance and flow. Instantaneous $\mathrm{Cl}$ concentrations, based on specific conductance and flow data collected every 10 minutes, were calculated for the period of available record at each station from November 2008 to September 2009.

The variables specific conductance and natural log of estimated instantaneous streamflow were found to be significant in relating ancillary variables to the dependent variable $\mathrm{Cl}$ concentration at seven of the eight sites (table 7). The instantaneous streamflow estimates were made at each of the four downstream sites but were significant when applied to the corresponding upstream site as well. At Oil Mill Brook downstream from I-95, the variable instantaneous flow was significant at $p$ less than 0.05 , but natural $\log$ of instantaneous flow was not. The use of the instantaneous flow variable improved the fit of each regression model and helped to explain additional variability, in comparison with the traditional method of using only specific conductance in a simple linear regression.

\section{Estimation of Cl Loads and Yields}

$\mathrm{Cl}$ loads in streams were estimated for each of the four sites downstream from I-95. Loads were estimated by multiplying the daily mean estimated $\mathrm{Cl}$ concentration by the daily mean streamflow for each day with available record. Total $\mathrm{Cl}$ loads in streams for the period of record were summarized along with daily loads and daily yields per square mile of watershed area. Lower and upper bounds of a 95-percent confidence interval were calculated for estimated $\mathrm{Cl}$ concentrations, and subsequently for daily $\mathrm{Cl}$ load and yield, to provide a range of plausible values.

Mean chloride yields per square mile at the downstream monitoring sites at Four Mile River, Oil Mill Brook, Stony Brook, and Jordan Brook were compared with annual $\mathrm{Cl}$ yield 
.

$\stackrel{c}{\square}$

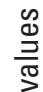

$\frac{1}{2}$

สิ

兽

I

흔

힝

흥

荧

음

冚

. ฮ

递 잉

음

응

4

\& 은

苑

क

ᄃ

응 응

힝

인

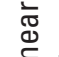

$\stackrel{9}{\Xi}$

응

를

高

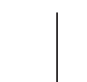

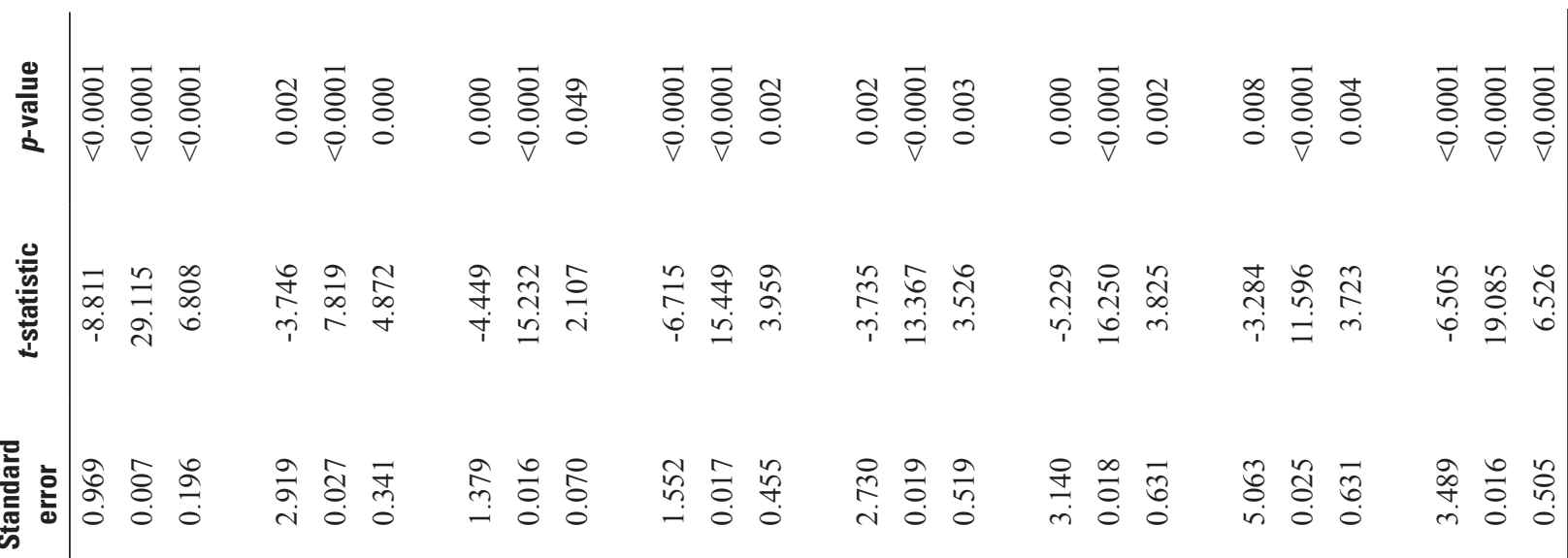

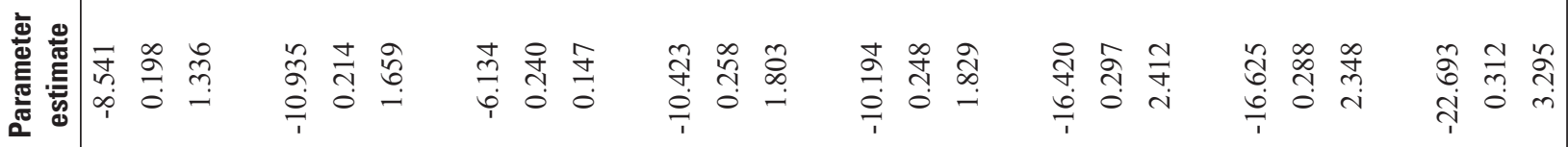

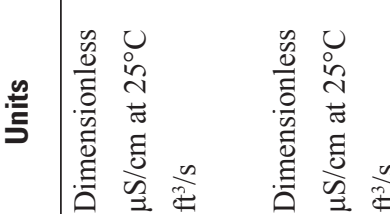

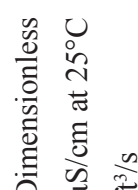

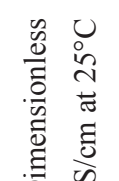

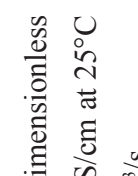

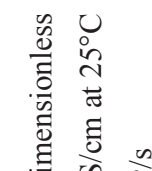

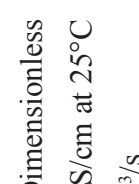

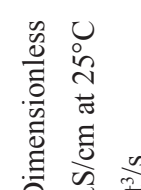
氖
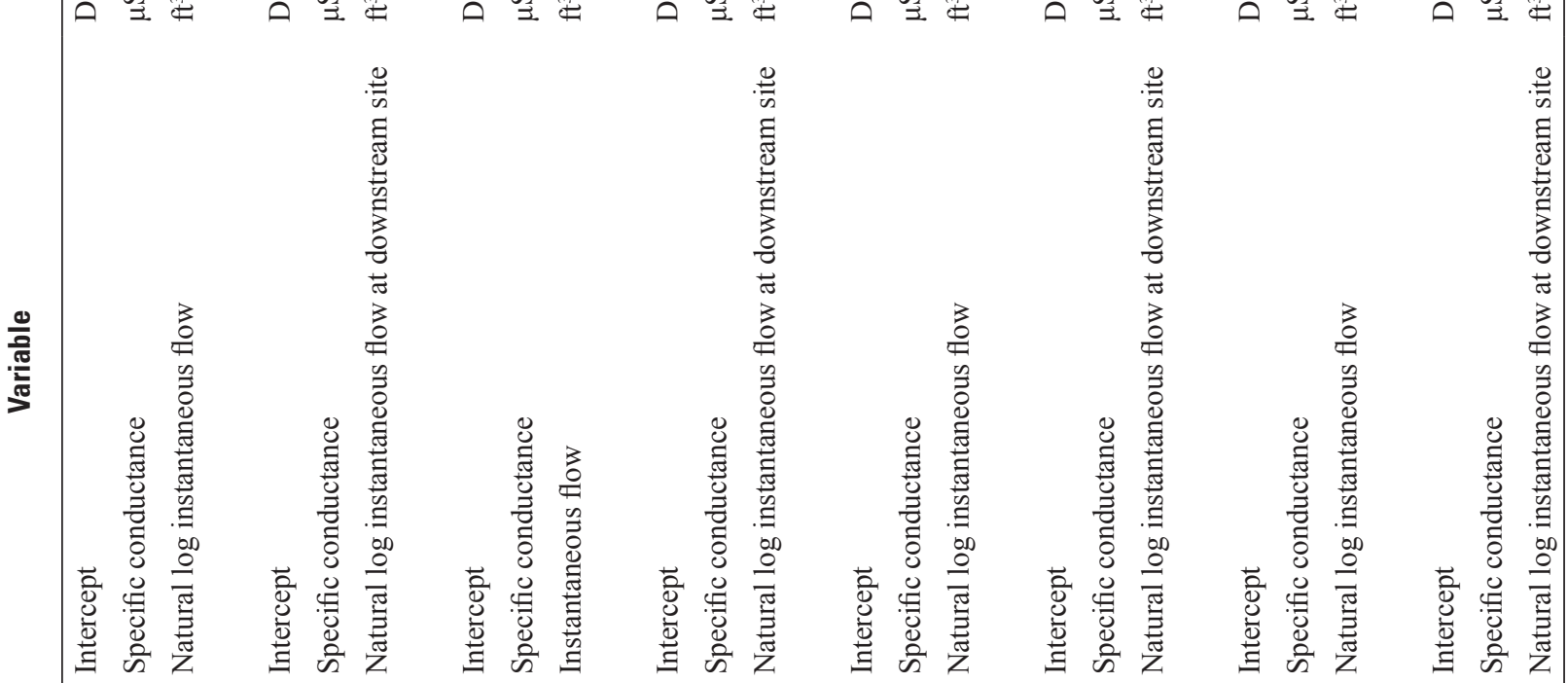

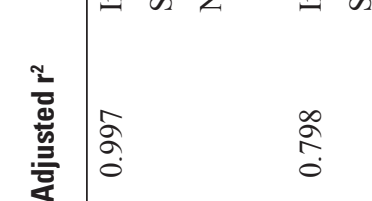
:
善
홍
$\frac{n}{2}$
$\stackrel{\infty}{\circ}$
:

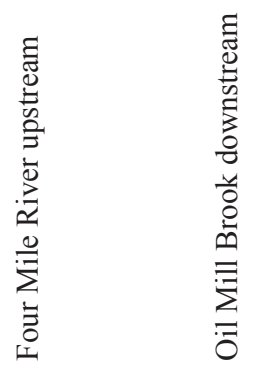

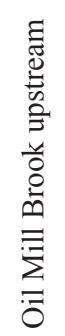

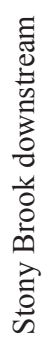

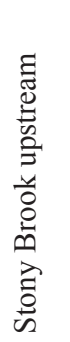

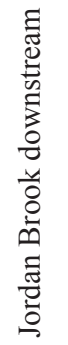

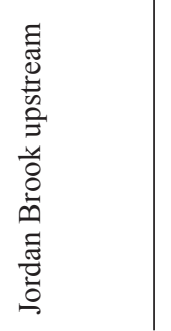


estimates for 10 selected rivers in Connecticut for 1998 to 2007 that were determined using the LOAD ESTimator (LOADEST) computer program (Runkel and others, 2004). LOADEST was used to estimate $\mathrm{Cl}$ yields for the 10 selected rivers in Connecticut by multiplying the daily mean estimated $\mathrm{Cl}$ concentration by the daily mean streamflow for each day with available record. Given a time series of streamflow, additional data variables, and constituent concentration, LOADEST assists the user in developing a regression model for the estimation of constituent load. Explanatory variables in the regression model include various functions of streamflow, decimal time, and additional user-specified data. The formulated regression model then is used to estimate loads over a user-specified time interval.

\section{Preliminary Assessment of the Effects of Road Deicers on Water Quality}

Specific conductance and $\mathrm{Cl}$ concentrations varied temporally with streamflow and season, and spatially between upstream and downstream sites on each of the four streams as described below.

\section{Weather Data and Storm Events}

The spatially averaged annual total precipitation in Connecticut over the last 100 years shows a generally upward trend in precipitation with high year-to-year variability. The long-term mean annual precipitation is $44.8 \mathrm{in} / \mathrm{yr}$ and is distributed fairly evenly throughout the year (Miller and others, 2002). The average annual precipitation near the coast at Groton-New London airport weather station (fig. 2) is $48.7 \mathrm{in}$. for a 39 -year period of record. Snowfall is a minor component of the total precipitation in Connecticut, particularly along the coastal regions where it is moderated by the ocean. The average snowfall in Connecticut is approximately $30 \mathrm{in}$. along the coast, $40 \mathrm{in}$. inland, and $60 \mathrm{in}$. in the northwest corner of the state (Miller and others, 2002). The average annual snowfall at Groton is 36.9 in. with an average winter temperature of $-1.8^{\circ} \mathrm{C}$.

Weather data, including maximum and minimum daily air temperature, precipitation amount (fig. 5A), measured and estimated thickness of snow, and estimated snow melt (fig. 5B), were compared to streamflow, specific conductance, and $\mathrm{Cl}$ concentration. Precipitation and (or) stormwater-runoff events generally coincide with an increased response of stream stage and streamflow. These responses also can be related to the type and amount of road deicers applied by ConnDOT to I-95 and associated roads in the Four Mile River watershed and in the Oil Mill Brook-Stony Brook-Jordan Brook watershed area in response to (or preceding) ice or snow events (table 5).
Streamflow varied among sites from a mean of $4.8 \mathrm{ft}^{3} / \mathrm{s}$ at Stony Brook to a mean of $14 \mathrm{ft}^{3} / \mathrm{s}$ at Four Mile River (fig. 6). Streamflow data were compared to precipitation events and stream chemistry to help determine sources and timing of $\mathrm{Cl}$ concentrations and loads.

\section{Water Quality}

Estimated $\mathrm{Cl}$ concentrations at the four stream sites were well below the chronic aquatic-habitat criteria for $\mathrm{Cl}$ of $230 \mathrm{mg} / \mathrm{L}$ over a 4-day average. Generally, the specific conductance and $\mathrm{Cl}$ concentrations in grab samples and continuous specific conductance and estimated $\mathrm{Cl}$ concentrations at downstream monitoring sites were higher during winter months than at other times of the year; increases corresponded to precipitation or melting events and increased streamflow, as discussed in "Stormflow Chemistry" below. During the spring and summer months, specific conductance and $\mathrm{Cl}$ concentration generally decreased in response to precipitation events and peaks in streamflow that cause dilution. Median continuous specific conductance and estimated $\mathrm{Cl}$ concentrations were lowest at the Four Mile River upstream site ( $82 \mu \mathrm{S} / \mathrm{cm}$ and $11 \mathrm{mg} / \mathrm{L}$, respectively) and highest at the Jordan Brook upstream site $(200 \mu \mathrm{S} / \mathrm{cm}$ and $45 \mathrm{mg} / \mathrm{L}$, respectively) from November 1, 2008, through September 30, 2009 (table 8A).

\section{Base-Flow Chemistry}

Stream sites were sampled on August 19, 2009, during base-flow conditions to determine the background major-ion chemistry of groundwater. Concentrations of major ions in samples collected at all eight sites during base flow, and in other samples collected at the Oil Mill Brook and Stony Brook upstream sites during higher flows in February and March 2009, are depicted on Stiff diagrams in figure 7. $\mathrm{Cl}$ and $\mathrm{Na}$ were the dominant ions in samples collected during base flow at most sites and during higher flows at the Oil Mill Brook upstream site and the Stony Brook downstream site (fig. 7). Concentrations of $\mathrm{Cl}$ and $\mathrm{Na}$ in samples collected at Four Mile River and Stony Brook during base flow were higher at the downstream sites than at the upstream sites and probably reflect the greater contributions of shallow groundwater that was affected by deicing chemicals downstream from I-95. The concentrations of bicarbonate $\left(\mathrm{HCO}_{3}^{-}\right), \mathrm{Ca}$, and magnesium $(\mathrm{Mg})$ at Four Mile River were comparable to concentrations of $\mathrm{Cl}$ and $\mathrm{Na}$ and may indicate a leachate source from a landfill that is upstream from I-95 (fig. 1). The concentrations of major ions at Oil Mill Brook and Jordan Brook during base flow were very similar for the upstream and downstream sites. At the Oil Mill Brook upstream site, concentrations of $\mathrm{HCO}_{3}^{-}, \mathrm{Mg}$, and $\mathrm{Ca}$ increased, and concentrations of $\mathrm{Na}$, $\mathrm{Cl}$, and sulfate $\left(\mathrm{SO}_{4}{ }^{2-}\right)$ decreased, from February to August 2009, apparently as contributions from road-deicing sources 

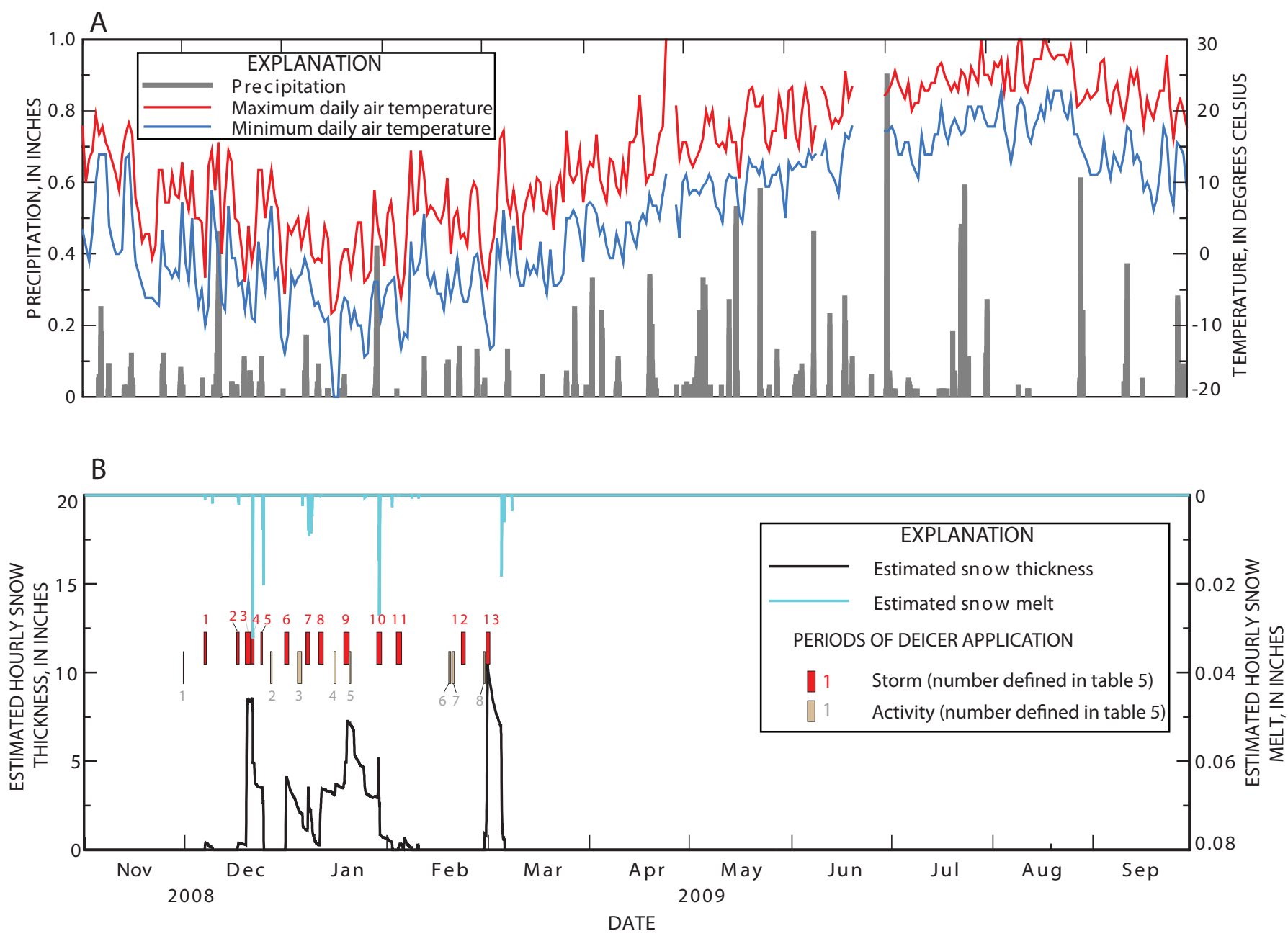

Figure 5. A, Maximum and minimum daily air temperature and continuous precipitation at the Groton-New London airport weather station, and $B$, estimated hourly snow thickness and snow melt at a snow observation station in southeastern Connecticut, November 2008-September 2009. (Details on application of deicers are shown in tables 4 and 5. )

decreased and contributions from base flow increased throughout the spring and summer. Major ion concentrations in base flow at the Four Mile River sites are comparable to concentrations in shallow groundwater from undeveloped areas. Concentrations of major ions in groundwater samples from three shallow wells in forested areas in Connecticut (Grady and Mullaney, 1998) indicate patterns of ions that are less dominated by $\mathrm{Na}$ and $\mathrm{Cl}$ than in stream-water samples that have relatively high concentrations of $\mathrm{Ca}, \mathrm{Mg}$, and $\mathrm{HCO}_{3}$ (fig. 7).

\section{Stormflow Chemistry}

During winter months, specific conductance and $\mathrm{Cl}$ concentrations in streams generally increased with precipitation or melting events and subsequent increases in streamflow as a result of road deicers washed from road surfaces by stormwater. Periods of increased continuous specific conductance and estimated $\mathrm{Cl}$ concentrations were observed at downstream monitoring sites (1) in direct response to a storm or deicing activity (figs. 8-11; table 5) or (2) during a period of rain or melting that occurred after a storm or activity. Most of the increase in $\mathrm{Cl}$ concentrations between upstream and downstream sites probably resulted from deicing salts carried in stormwater washed from I-95 highway lanes, ramps, access roads (table 4), other state or town roads, parking lots, sidewalks, and driveways. Specific conductance and $\mathrm{Cl}$ concentrations at upstream monitoring sites generally decreased during precipitation and melting events as a result of dilution. Some upstream monitoring sites, however, including the Stony Brook upstream site (011277916), showed increased specific conductance and $\mathrm{Cl}$ concentrations during these events because some runoff from the highway is discharged to the upstream watershed. During the spring and summer months, specific conductance in continuous measurements and $\mathrm{Cl}$ concentrations in samples generally decreased in response 


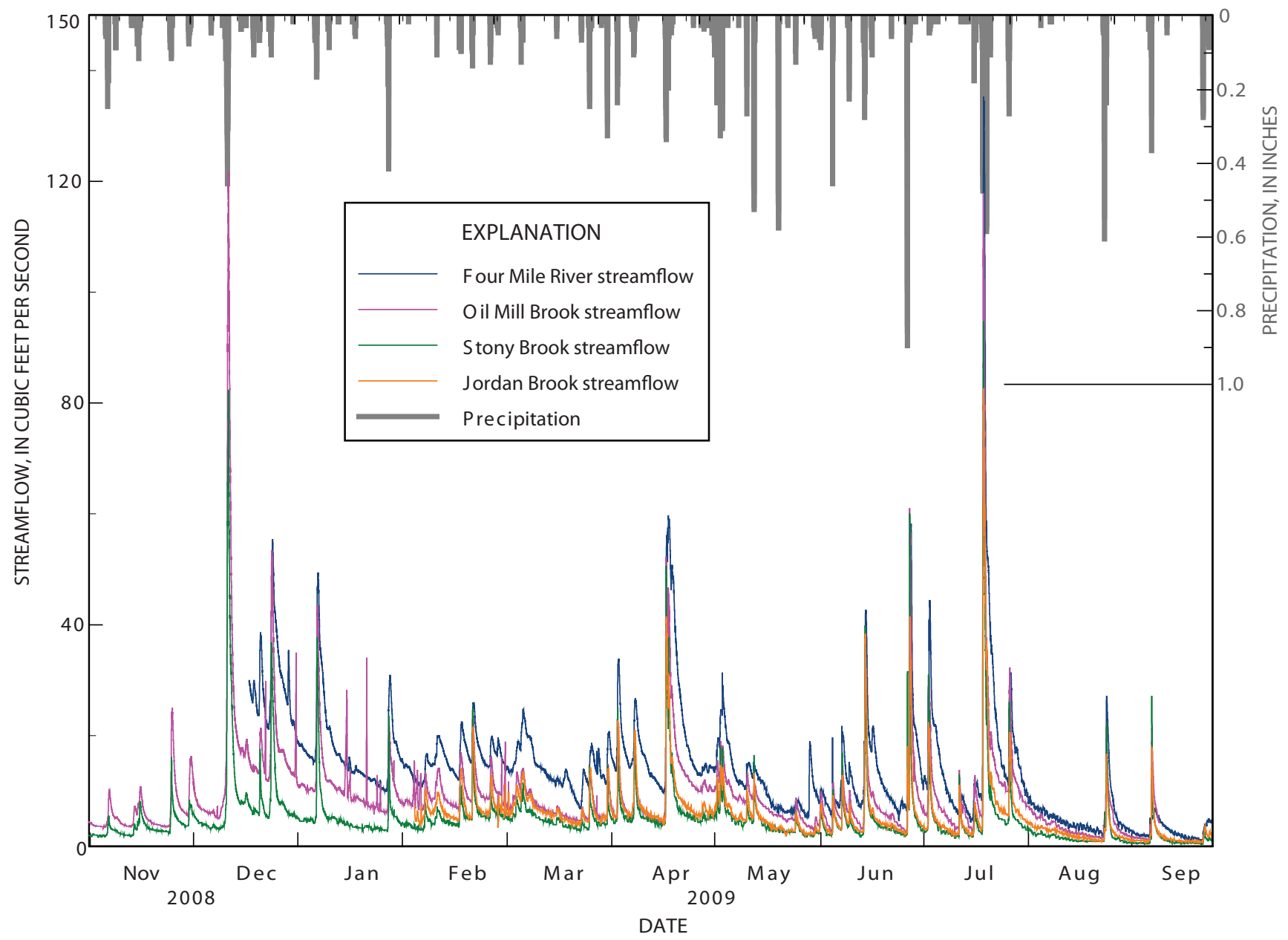

Figure 6. Continuous streamflow at the downstream monitoring sites at Four Mile River, Oil Mill Brook, Stony Brook, and Jordan Brook, and precipitation at Groton-New London airport weather station, southeastern Connecticut, November 2008-September 2009.

to precipitation events and subsequent increases in streamflow. According to ConnDOT records, no road deicers were applied to state roads after March 2, 2009, during the 2008-09 winter season (table 5 and fig. 5). The continued increase in specific conductance and estimated $\mathrm{Cl}$ concentrations with increased stormflow at some sites after about April 21, 2009, when daily mean temperatures exceeded $0^{\circ} \mathrm{C}$ and all snow had melted indicates that high concentrations of $\mathrm{Cl}$ and other deicing constituents were retained in soils and or shallow groundwater and continued to affect stream chemistry through the early part of the spring.

\section{Four Mile River}

Water-quality data at the Four Mile River upstream and downstream sites were recorded continuously from January 12, 2009, and December 19, 2008, respectively, through the interim study period. Median specific conductance and estimated $\mathrm{Cl}$ concentrations were slightly higher at the downstream site than at the upstream site through the study period (table 8A and fig. 8). During winter months, specific conductance and $\mathrm{Cl}$ concentrations at the downstream site increased in response to several deicing events - winter storms $4,5,7,10$, and 12 and activity 6 , and rain or snow melting events on February 12 and February 27, 2009 (fig. 8 and table 5). The estimated amount of salt applied to I-95 and associated roads in the Four Mile River area indicate that, although the date and amount of deicers applied to state roads correspond to increases in specific conductance in some cases (table 5 and fig. 8A), the response in stream chemistry better relates to both the cumulative amount and period of deicer application in addition to the occurrence of rain and (or) warm temperatures and subsequent melting that washes deicers into the stream. For example, storms 4 and 5 (fig. 5B), which represent the first winter storms during the recording of data at the Four Mile River downstream site, resulted in increased levels of specific conductance and estimated $\mathrm{Cl}$ concentrations in the stream (fig. 8). However, deicers applied during storm 

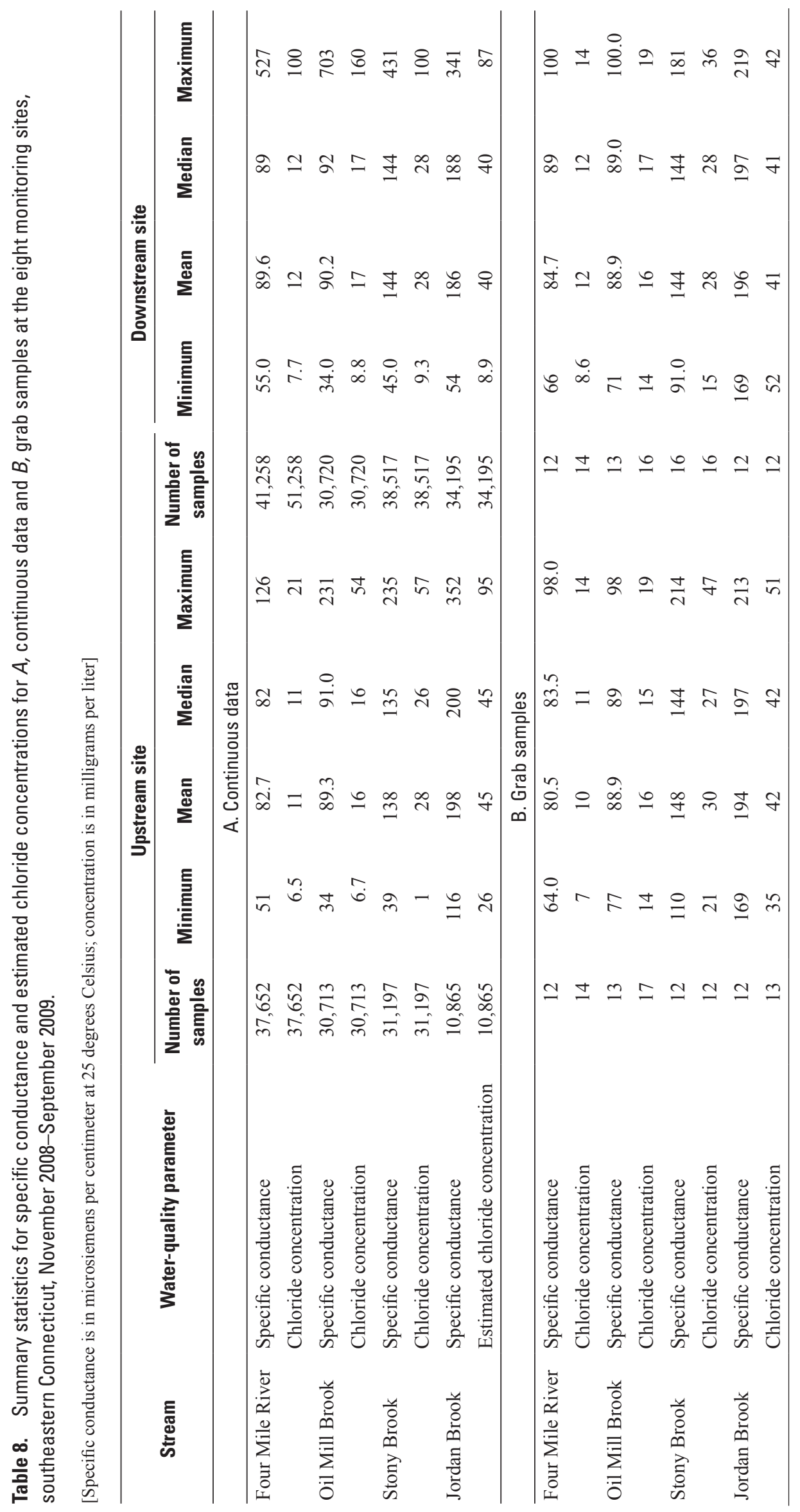


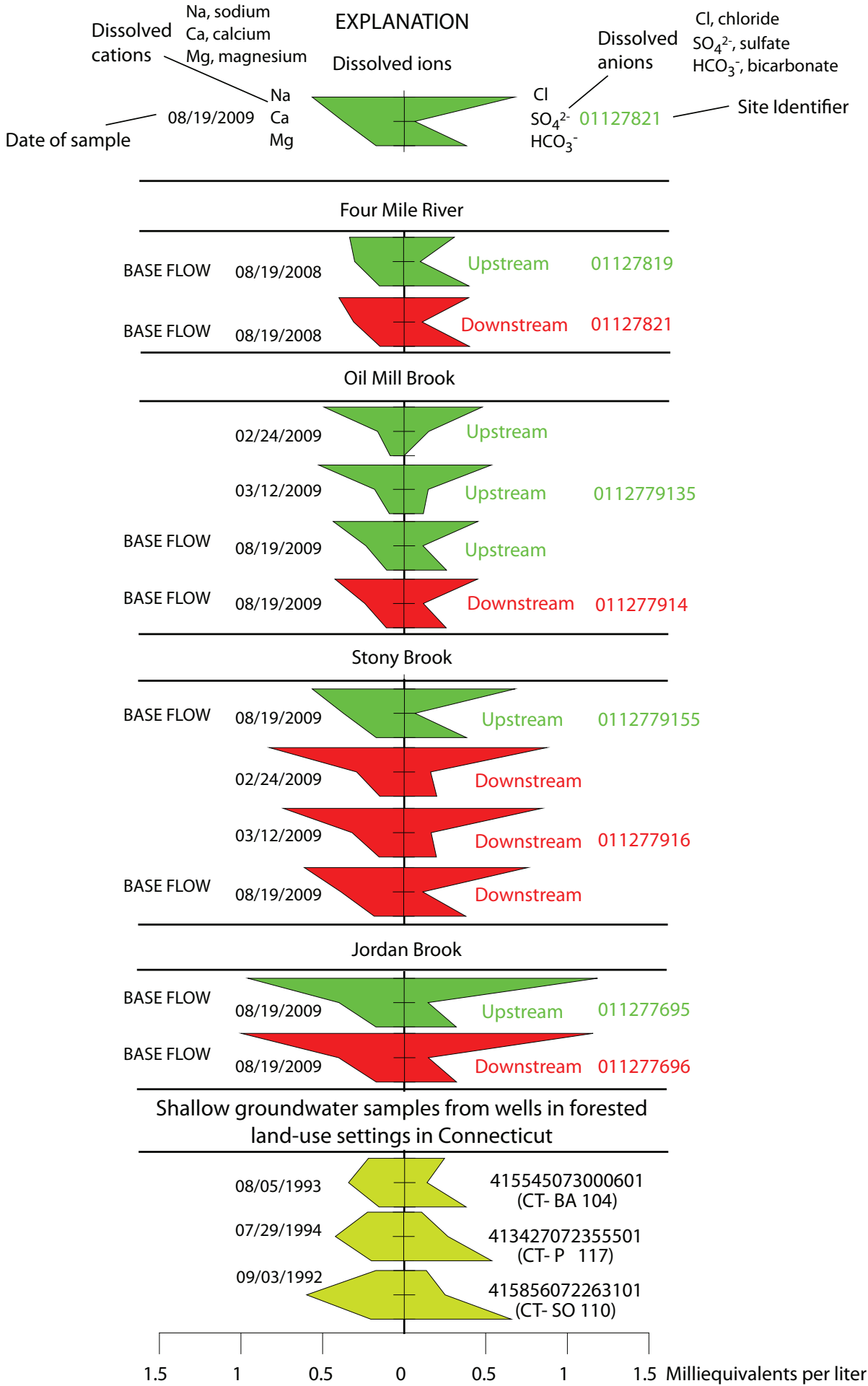

Figure 7. Diagrams depicting the concentrations of major ions in water at upstream and downstream monitoring sites at Four Mile River, Oil Mill Brook, Stony Brook, and Jordan Brook, southeastern Connecticut, and shallow groundwater samples from wells in forested land-use settings in Connecticut. 

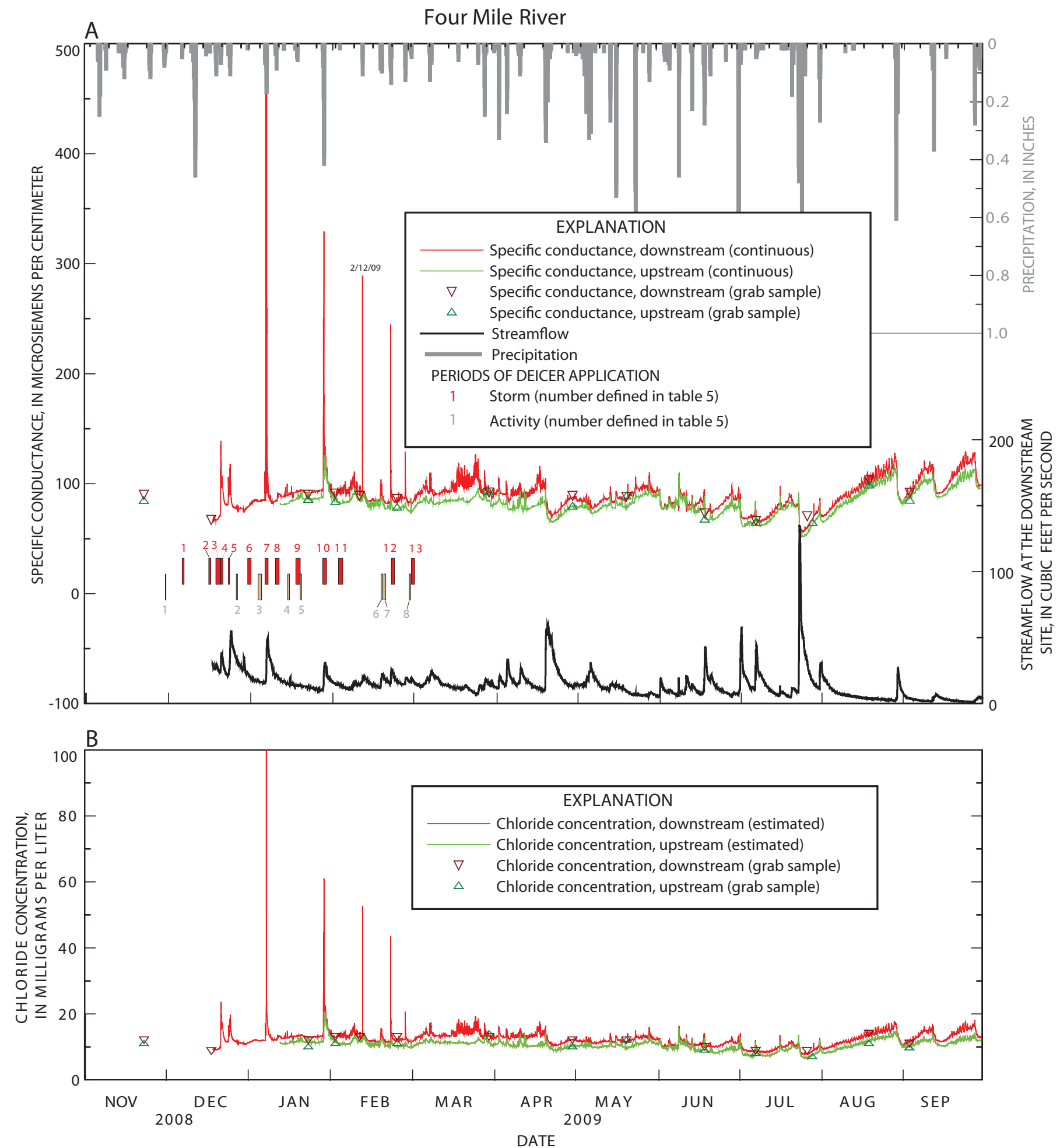

Figure 8. A, Specific conductance in grab samples, continuous specific conductance at Four Mile River upstream and downstream sites, continuous streamflow at the downstream site, and precipitation at Groton-New London airport weather station, and $B$, chloride concentrations measured in grab samples and estimated continuous chloride concentrations at Four Mile River upstream and downstream sites, southeastern Connecticut, November 2008-September 2009. 
6 , which consisted of several inches of snow with cold temperatures and no rain, and activities 2 and 3 (fig. 5B) did not lead to any observed response in specific conductance at the Four Mile River downstream site (fig. 8), most likely because of the subfreezing temperatures and absence of rain or melting and subsequent runoff. Storm 7 consisted of snow followed by rain and resulted in the highest specific conductance $(527 \mu \mathrm{S} / \mathrm{cm})$ and estimated $\mathrm{Cl}$ concentration (100 mg/L) during winter for this site (fig. 8 and table 8). An estimated 28.6 tons of $\mathrm{NaCl}$ and 307 gal of $\mathrm{CaCl}_{2}$ were applied to I-95 and associated state roadways (table 5) in the "frozen" period between the end of storm 5 on December 24 and the beginning of the increased levels of specific conductance on January 7 at 6 a.m., 14 hours into the deicer application. A similar cold period between storm 7 and storm 10 (during January 27-29) showed no increases in specific conductance or estimated $\mathrm{Cl}$ concentrations in response to applications for storms 8 and 9 . Finally, the period between storm 10 and storm 12, and the deicer applications in between, had no major increases in specific conductance, except during a rain event on February 12, 2009, when specific conductance reached $289 \mu \mathrm{S} / \mathrm{cm}$.

\section{Oil Mill Brook}

Water-quality data at the Oil Mill Brook upstream and downstream sites were recorded continuously beginning January 7, 2009, through the interim study period; however, data are missing for the period from February 4 to March 13, 2009, because of equipment failure. Specific conductance and estimated $\mathrm{Cl}$ concentrations were slightly higher at the downstream site than at the upstream site until the middle of August 2009 when values at the downstream site became slightly higher (fig. 9).

Specific conductance and estimated $\mathrm{Cl}$ concentrations increased at Oil Mill Brook upstream and downstream sites in response to winter storms 7, 8, and 10 and increased streamflow (fig. 9). Larger increases in specific conductance and estimated $\mathrm{Cl}$ concentrations at the downstream site than at the upstream site in response to storms 7, 8, and 10 likely were caused by deicers washed from I-95. At the downstream site, stormwater runoff from a local road and bridge was observed to flow into the stream near the monitor and may have affected specific conductance and estimated $\mathrm{Cl}$ concentrations during snow melt. In March 2010 (after the interim period of study), an additional monitor was added upstream from the existing monitor to measure conditions that are not affected by runoff from the town road.

\section{Stony Brook}

Water-quality data for Stony Brook were recorded continuously from January 6, 2009, at the downstream site and from February 2, 2009, at the upstream site through the interim study period (fig. 10); however, specific conductance and estimated $\mathrm{Cl}$ concentration data for the upstream site are missing for the period from May 20-29, 2009, because of equipment failure. Median specific conductance and estimated $\mathrm{Cl}$ concentrations were slightly higher at the downstream site than at the upstream site through the study period (table 8A). Specific conductance was elevated at the Stony Brook downstream site during discharge events on January 7 (storm 7), January 28 (storm 10), and February 2-4, 2009 (storm 11), and during other deicing activities on February 18-19 and 19-20 (activities 6 and 7), presumably by increased concentrations of $\mathrm{Cl}, \mathrm{Na}$, and other ions in deicing chemicals washed off roads. Specific conductance and estimated $\mathrm{Cl}$ concentrations in February and early March, however, generally decreased during discharge events because of dilution (fig. 10). Specific conductance and estimated $\mathrm{Cl}$ concentrations were slightly higher at the downstream site than at the upstream site throughout the period of record with two exceptions. During February 15-18, 2009, elevated levels of specific conductance might have resulted from some melting of remaining snow near I-95 or other upstream roads; as discussed previously, some drainage from I-95 flows to the north and likely affects the upstream site water-quality monitor. Upstream and downstream sites are $0.82 \mathrm{mi}$ apart; therefore, another possible cause for this discrepancy could be dilution from groundwater and (or) stormwater runoff between the upstream and downstream sites that acts to dampen the increase at the downstream site. Specific conductance also was higher at the upstream site than at the downstream site during August and September 2009. The reason for the increase at the upstream site is not known, but the absence of an increase in specific conductance at the downstream site could result from dilution. Elevated levels of specific conductance at the downstream site on March 9 and 12-13 were associated with rain events or warm air temperatures and likely resulted from salts in melting snow piles and (or) deicing salts that were flushed from soils and shallow groundwater, then discharged downstream. Studies have reported a substantial portion (45 to 85 percent) of $\mathrm{Cl}$ in deicers is not removed by overland flow but infiltrates into soils and (or) groundwater (Howard and Haynes, 1993; Church and Friez, 1993; Toler and Pollock, 1974).

\section{Jordan Brook}

Water-quality data for the Jordan Brook upstream and downstream sites were recorded continuously beginning February 5, 2009 (fig. 11). Median specific conductance and estimated $\mathrm{Cl}$ concentrations were slightly lower at the downstream site than at the upstream site throughout the study period (table 8A). Runoff from a parking lot adjacent to the upstream site likely contributed deicing salts in winter and early spring; base flow, which can include anthropogenic sources such as septic-tank drainfields, is also a possible contributor of salts throughout the year. Specific conductance and estimated $\mathrm{Cl}$ concentrations generally increased concurrently at the Jordan Brook upstream and downstream sites during winter and early spring discharge events. Increased levels of specific conductance and estimated 

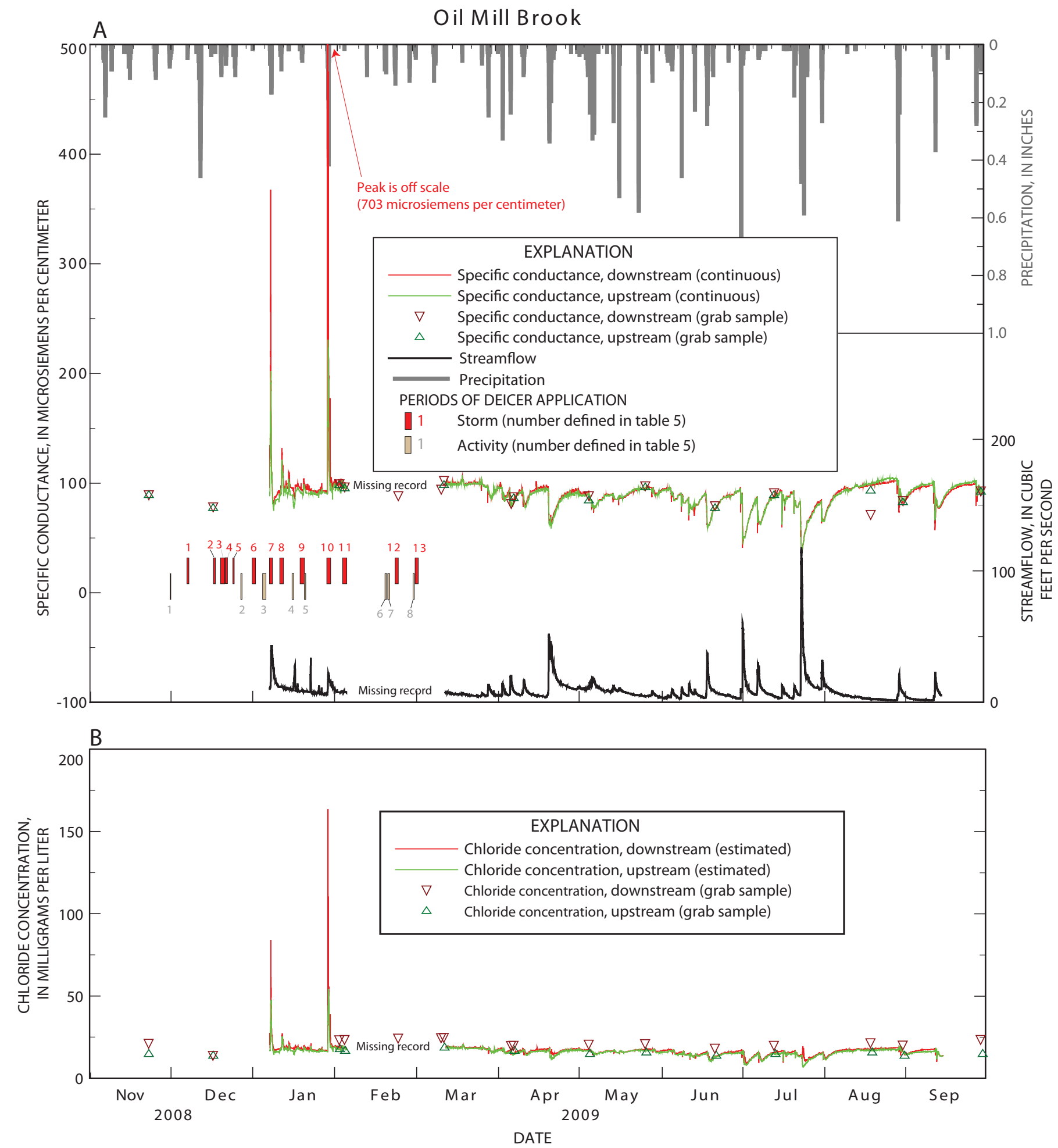

Figure 9. A, Specific conductance in grab samples and continuous specific conductance at Oil Mill Brook upstream and downstream sites, continuous streamflow at the downstream site, and precipitation at Groton-New London airport weather station, and $B$, chloride concentrations measured in grab samples and estimated continuous chloride concentrations at Oil Mill Brook upstream and downstream sites, southeastern Connecticut, November 2008-September 2009. 

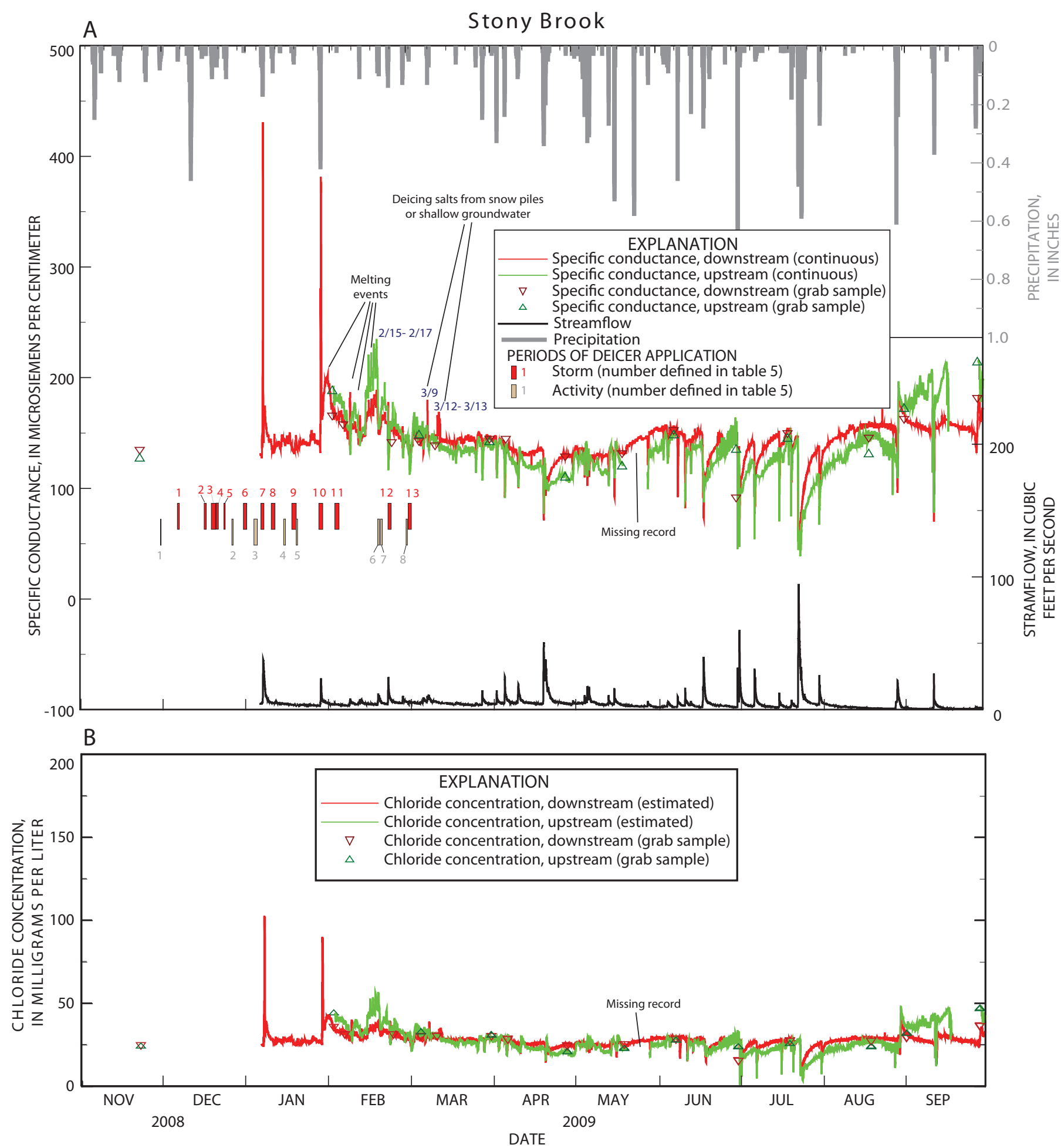

Figure 10. A, Specific conductance in grab samples and continuous specific conductance at Stony Brook upstream and downstream sites, continuous streamflow at the downstream site, and precipitation at Groton-New London airport weather station, and $B$, chloride concentrations measured in grab samples and estimated continuous chloride concentrations at Stony Brook upstream and downstream sites, southeastern Connecticut, November 2008-September 2009. 

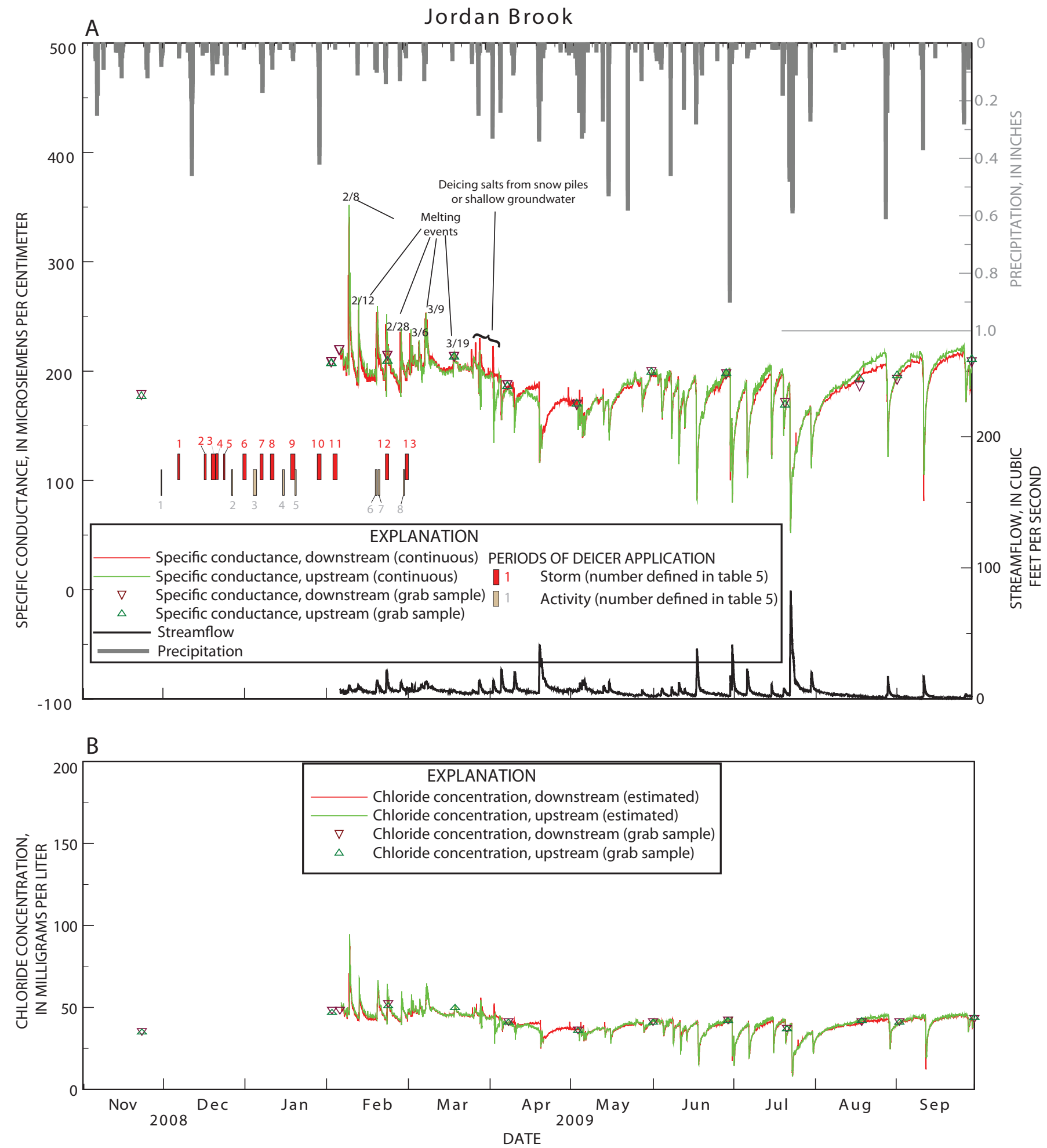

Figure 11. A, Specific conductance in grab samples and continuous specific conductance at Jordan Brook upstream and downstream sites, continuous streamflow at the downstream site, and precipitation at Groton-New London airport weather station, and $B$, chloride concentrations measured in grab samples and estimated continuous chloride concentrations at Jordan Brook upstream and downstream sites, southeastern Connecticut, November 2008-September 2009. 
$\mathrm{Cl}$ concentrations coincided with several winter storms or deicing activities, presumably as a result of $\mathrm{Cl}$ and other ions washed from road surfaces. Increases in specific conductance and $\mathrm{Cl}$ concentration on January 28 coincided with storm 10, and the multiple peaks during February 19 and March 2 coincided with deicing activities 6,7 , and 8 and storms 12 and 13 (table 5 and fig. 11). The highest specific conductance measured and $\mathrm{Cl}$ concentration estimated were $352 \mu \mathrm{S} / \mathrm{cm}$ and $95 \mathrm{mg} / \mathrm{L}$, respectively, on February 8; these values are associated with warm temperatures and melting of snow (figs. 5 and 11).

Specific conductance and estimated $\mathrm{Cl}$ concentrations commonly were highest at the upstream site and probably relate to the large percentage of adjacent impervious surfaces, relative to the downstream site, that were subjected to deicing chemicals. The application of deicing chemicals to several large parking lots to the west of the upstream site during snow or ice events resulted in high concentrations of $\mathrm{Cl}, \mathrm{Na}$, and other ions that were washed into Jordan Brook. Large mounds of snow that are plowed from impervious surfaces contain deicers that are released through melting, which occurs well after winter storm events. Increases in specific conductance and estimated $\mathrm{Cl}$ concentrations at upstream and downstream sites on February 28 and March 3, 6, 9, and 19, 2009 , probably resulted from delayed snow melt. Increases in specific conductance at the downstream site on March 26, 28, 29, and April 3, 2009, were associated with rain events and likely resulted from salts in melting snow piles and (or) $\mathrm{Cl}$ and other ions in deicers that were flushed from soils and shallow groundwater, then discharged downstream. A similar effect was observed at the Stony Brook downstream site (fig. 10). After April 3, specific conductance and estimated $\mathrm{Cl}$ concentrations in Jordan Brook decreased during precipitation and discharge events as a result of dilution (fig. 11).

\section{Chloride Loads}

Daily mean $\mathrm{Cl}$ concentrations were estimated for the periods of the study at each of the upstream and downstream sites, and daily loads were estimated for each of the downstream sites (figs. 12, 13, 14, and 15). The estimated daily mean $\mathrm{Cl}$ concentration at downstream sites, like instantaneous $\mathrm{Cl}$ concentrations, increased with streamflow (and stormwater runoff of road deicers) during most winter storms but decreased through dilution during the warmer months (figs. 12A, 13A, 14A, and 15A). Estimated daily loads, however, generally increased with streamflow and reflect the greater overall $\mathrm{Cl}$ amounts that were transported despite the dilution that occurred (figs. 12B, 13B, 14B, and 15B). $\mathrm{Cl}$ loads in streams generally were highest in the winter and early spring. Estimated $\mathrm{Cl}$ yields for the four monitoring sites downstream from Interstate 95 during the interim study period ranged from 17.3 tons per square mile (ton/ $\mathrm{mi}^{2}$ ) (98 tons total) at the Oil Mill Brook downstream site to 50 tons $/ \mathrm{mi}^{2}$ (140 tons total) at the Jordan Brook downstream site (table 9A). The estimated daily yield in the downstream sites ranged from
0.07 (ton $/ \mathrm{d}$ ) $/ \mathrm{mi}^{2}$ for Oil Mill Brook, which had the highest percentage of forest and wetland area, to 0.21 (ton/d) $/ \mathrm{mi}^{2}$ for Jordan Brook, which had the lowest percentage of forest and wetland area and the highest percentage of urban development. The lower and upper bounds of a 95-percent confidence interval for estimated $\mathrm{Cl}$ loads and yields show a narrow range of values and indicate reasonably low uncertainty in the predicted values (table 9A).

Based on data from the three NADP stations, the estimated percent contribution of $\mathrm{Cl}$ load from atmospheric deposition ranged from 9.5 to 94 tons for the Four Mile River watershed area and from 16 to 160 tons for the Oil Mill Brook-Stony Brook-Jordan Brook watershed area (table 9B). The contribution of $\mathrm{Cl}$ from atmospheric deposition to the watershed areas during the study period was 6.1, 7.1, and 60 percent for the Four Mile River watershed and 3.9, 4.3, and 36 percent at the Oil Mill Brook-Stony Brook-Jordan Brook watersheds area, based on the concentrations at the Abington, Conn., Lexington, Mass., and Cedar Beach, N.Y., NADP stations, respectively. The highest value is based on the concentration at the Cedar Beach, N.Y., NADP station, which is strongly affected by sea spray. Atmospheric deposition in the watersheds in this study, in general, should not be as affected by seawater as is the Cedar Beach station, so the values based on the NADP station in Lexington, Mass., are considered to be most representative of the contribution from atmospheric deposition.

The $\mathrm{Cl}$ loads in streams (outputs) were compared with $\mathrm{Cl}$ load inputs, including atmospheric deposition and deicer applications by ConnDOT and by towns (table 9B). Using data from the Lexington, Mass., NADP station, the $\mathrm{Cl}$ load inputs for the Four Mile River watershed represented about 32 percent of the $\mathrm{Cl}$ load leaving the watershed by the stream, and the $\mathrm{Cl}$ load inputs for the Oil Mill BrookStony Brook-Jordan Brook watersheds area represented about 69 percent of the $\mathrm{Cl}$ load leaving by the streams (table 9B). The percent contribution of chloride input that is unaccounted for in the mass balance for the watershed areas could be related to the lag period between the application of deicers and concentrations observed in streams, which is difficult to account for. Furthermore, this assessment of load balance is only qualitative and does not include the $\mathrm{Cl}$ load in groundwater leaving the study areas. Estimates of direct infiltration of $\mathrm{Cl}$ that originates from atmospheric deposition, deicer applications, septic-tank drainfields, and others sources of groundwater were not within the scope of this project.

$\mathrm{Cl}$ yields at the downstream monitoring stations at Four Mile River, Oil Mill Brook, Stony Brook, and Jordan Brook (table 9A) were compared with annual $\mathrm{Cl}$ yield estimates for 10 selected rivers in Connecticut during 1998-2007 that were estimated using LOADEST (fig. 16). Four Mile River and Oil Mill Brook had low estimated $\mathrm{Cl}$ yields, similar to yields at Bunnell (Burlington) Brook and Shetucket River, and reflect the low percentages of developed land and impervious area (table 1). Estimated $\mathrm{Cl}$ yields at Jordan Brook and Stony Brook were relatively high but were not as high as those for 

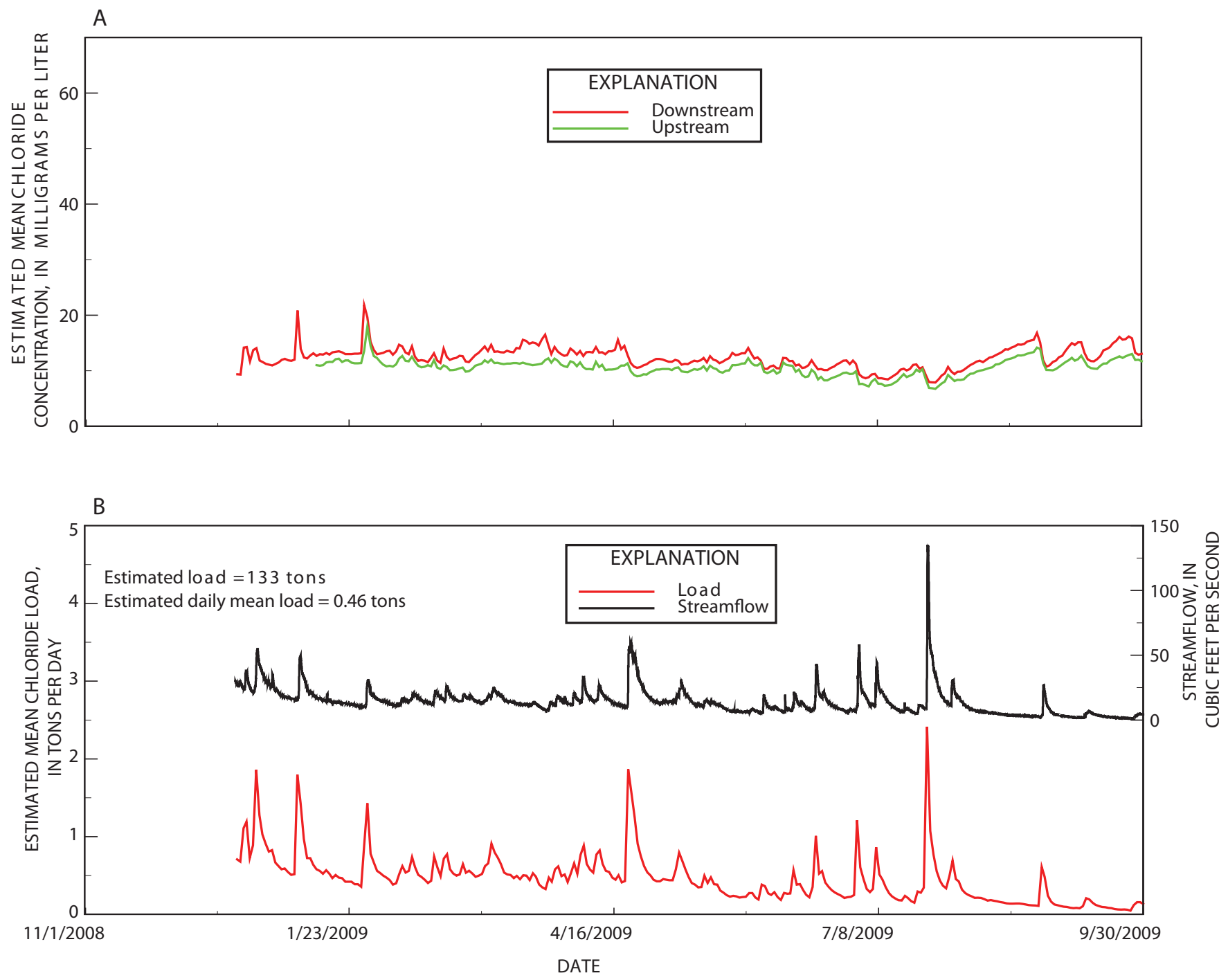

Figure 12. A, Estimated daily mean chloride concentrations at Four Mile River upstream and downstream sites, and $B$, estimated daily mean chloride load and streamflow for the Four Mile River downstream site, southeastern Connecticut, November 2008-September 2009. 

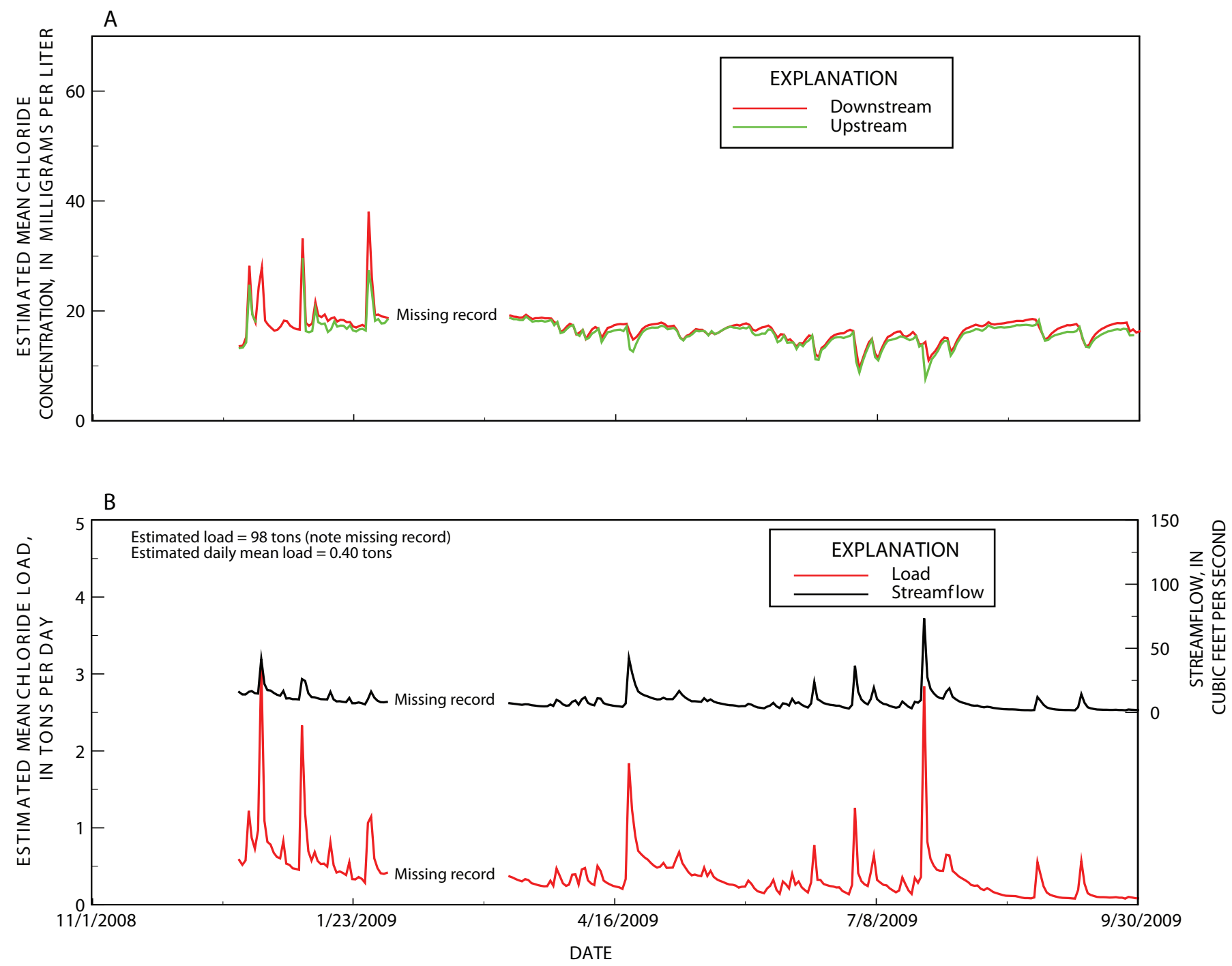

Figure 13. A, Estimated daily mean chloride concentrations at Oil Mill Brook upstream and downstream sites, and $B$, estimated daily mean chloride load and streamflow for the Oil Mill Brook downstream site, southeastern Connecticut, November 2008-September 2009. 

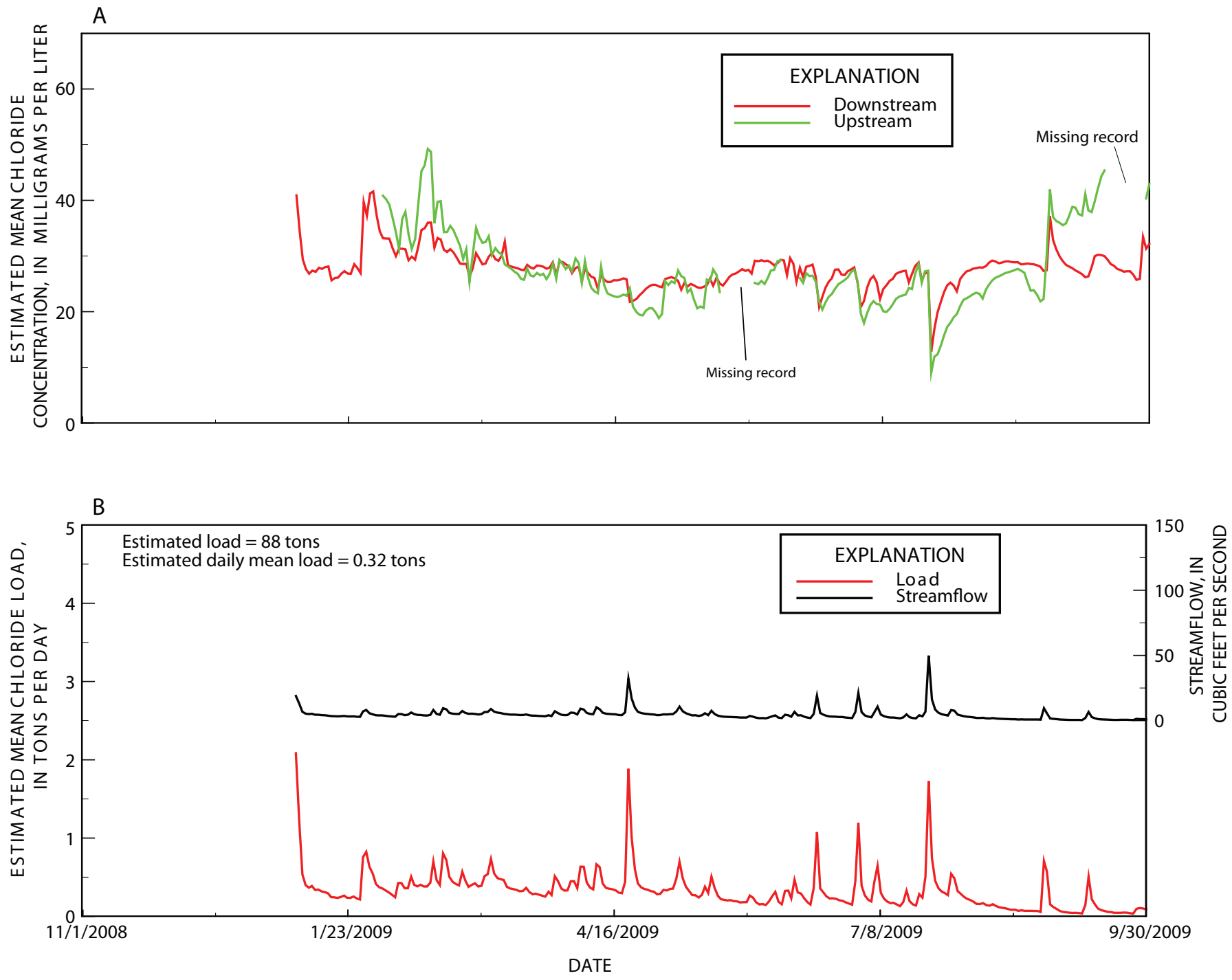

Figure 14. A, Estimated daily mean chloride concentrations at Stony Brook upstream and downstream sites, and $B$, estimated daily mean chloride load and streamflow for the Stony Brook downstream site, southeastern Connecticut, November 2008September 2009. 

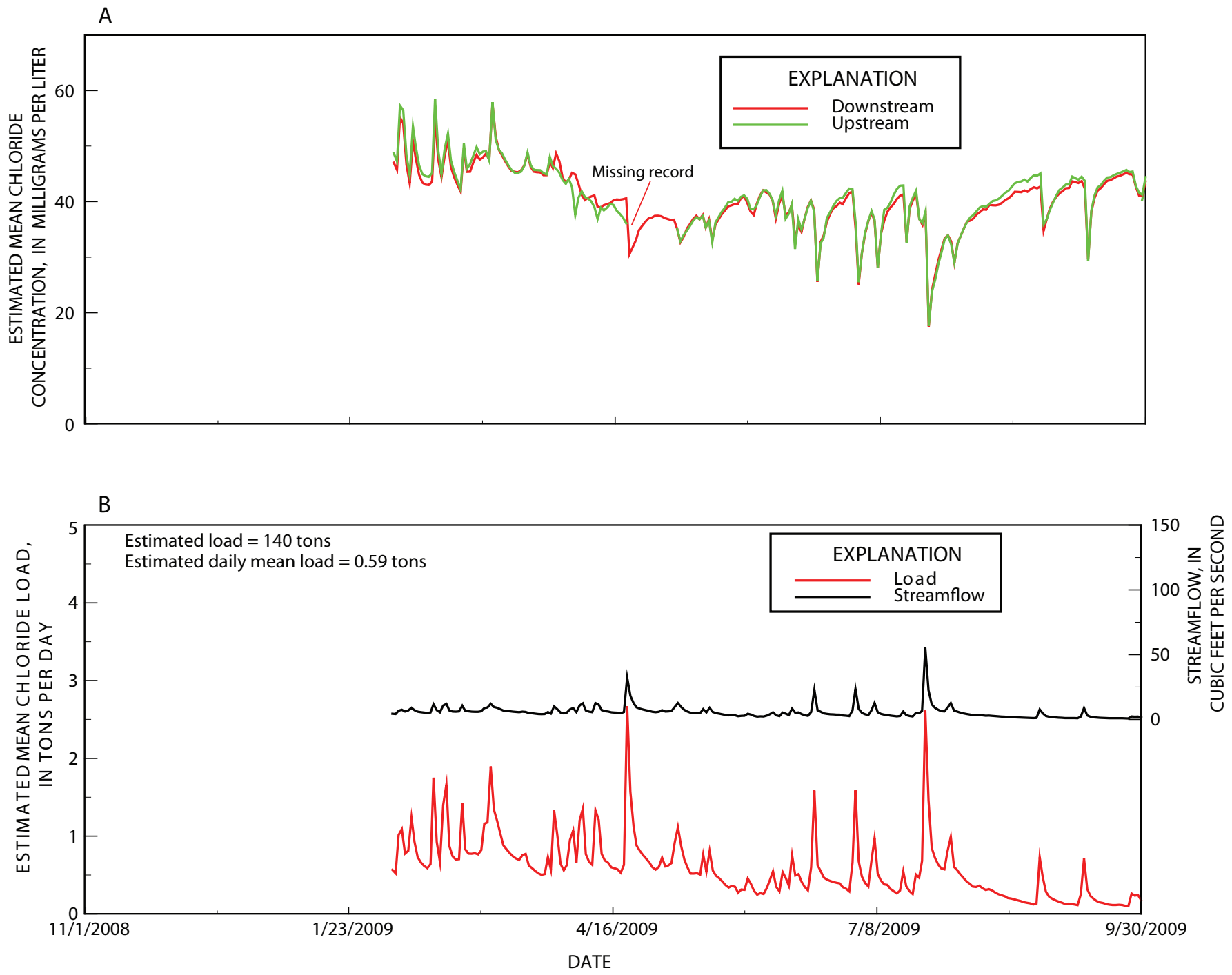

Figure 15. A, Estimated daily mean chloride concentrations at Jordan Brook upstream and downstream sites, and $B$, estimated daily mean chloride load and streamflow for the Jordan Brook downstream site, southeastern Connecticut, November 2008September 2009. 


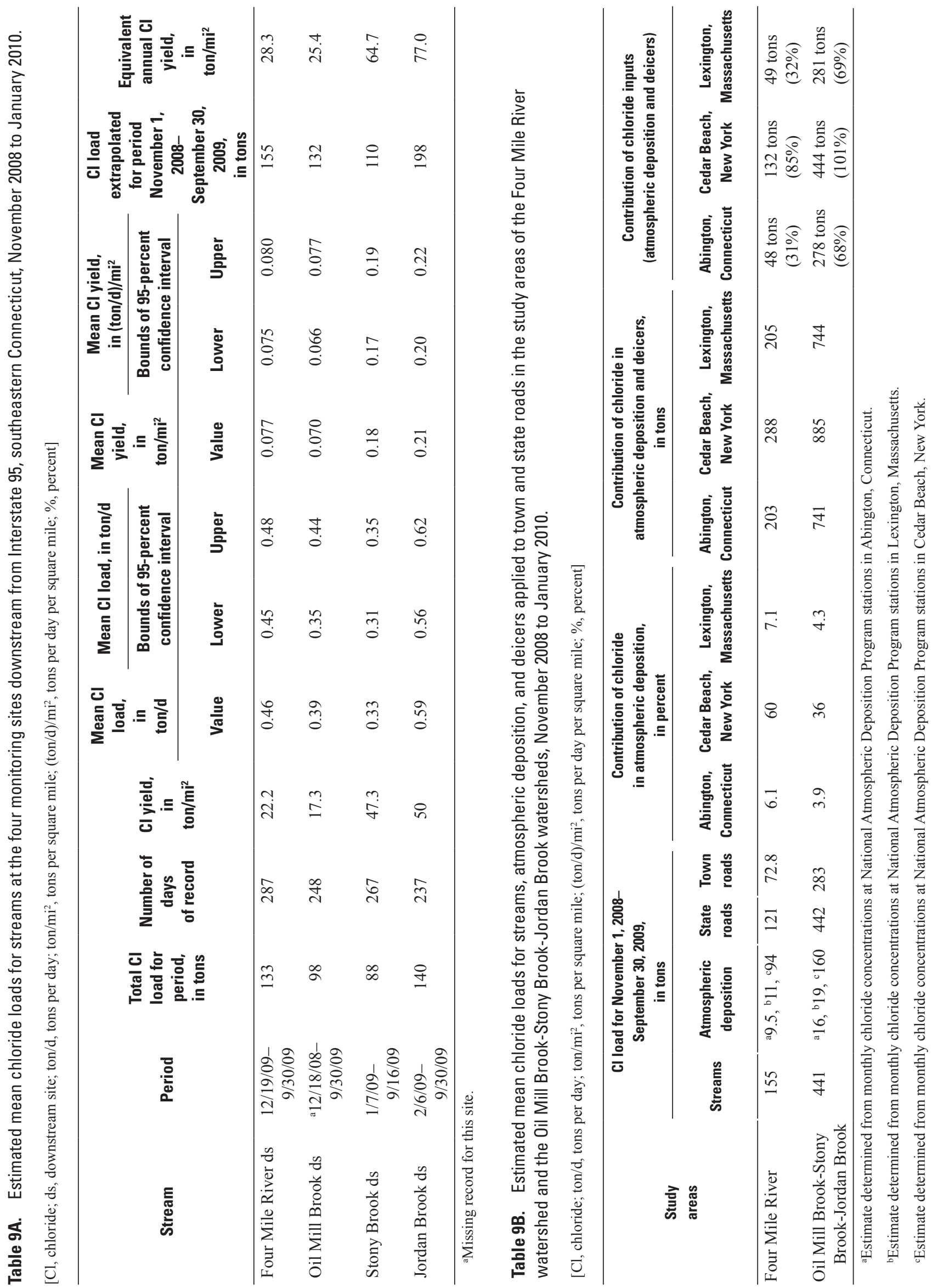




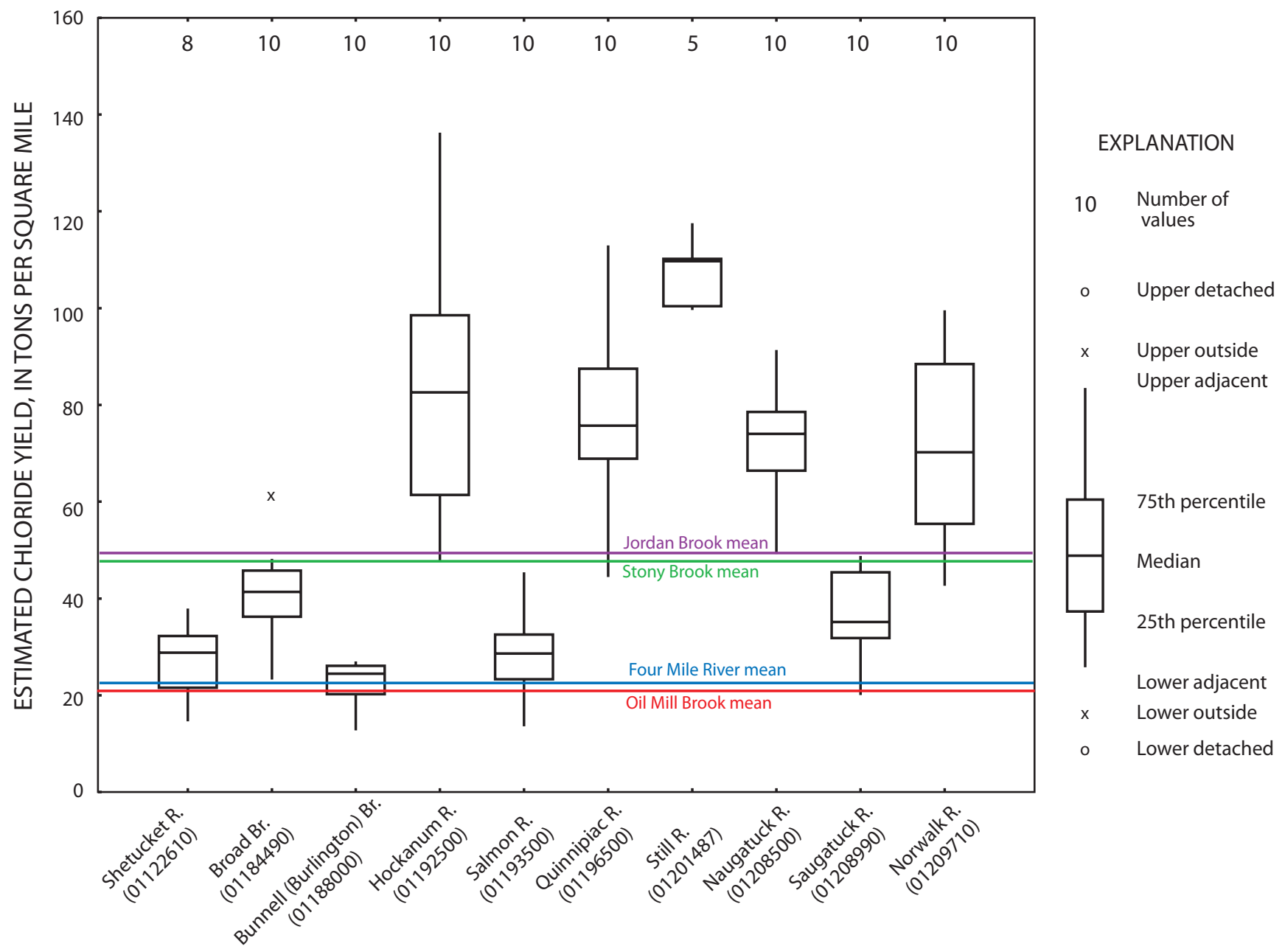

\section{U.S. GEOLOGICAL SURVEY MONITORING STATIONS}

Figure 16. Distribution of annual chloride yields estimated using LOADEST for selected rivers in Connecticut for water years 1998-2007, and estimated annual chloride yields for the downstream sites at Four Mile River, Oil Mill Brook, Stony Brook, and Jordan Brook for their periods of record. Estimated annual chloride yields are based on daily loads. (See table 9 for periods of record. R, River; Br, Brook) 
the more urbanized watersheds, such as those that drain the Still River at Brookfield Center and the Hockanum River (fig. 16). Cl yields for these sites were positively correlated with the percentage of impervious cover (U.S. Environmental Protection Agency, 2001; fig. 17) and probably reflect the application of deicers to roadways, as well as sources and practices associated with greater impervious cover such as wastewater and septic-system discharges, recycling of $\mathrm{Cl}$ from drinking water, and leachate from landfills and saltstorage areas.

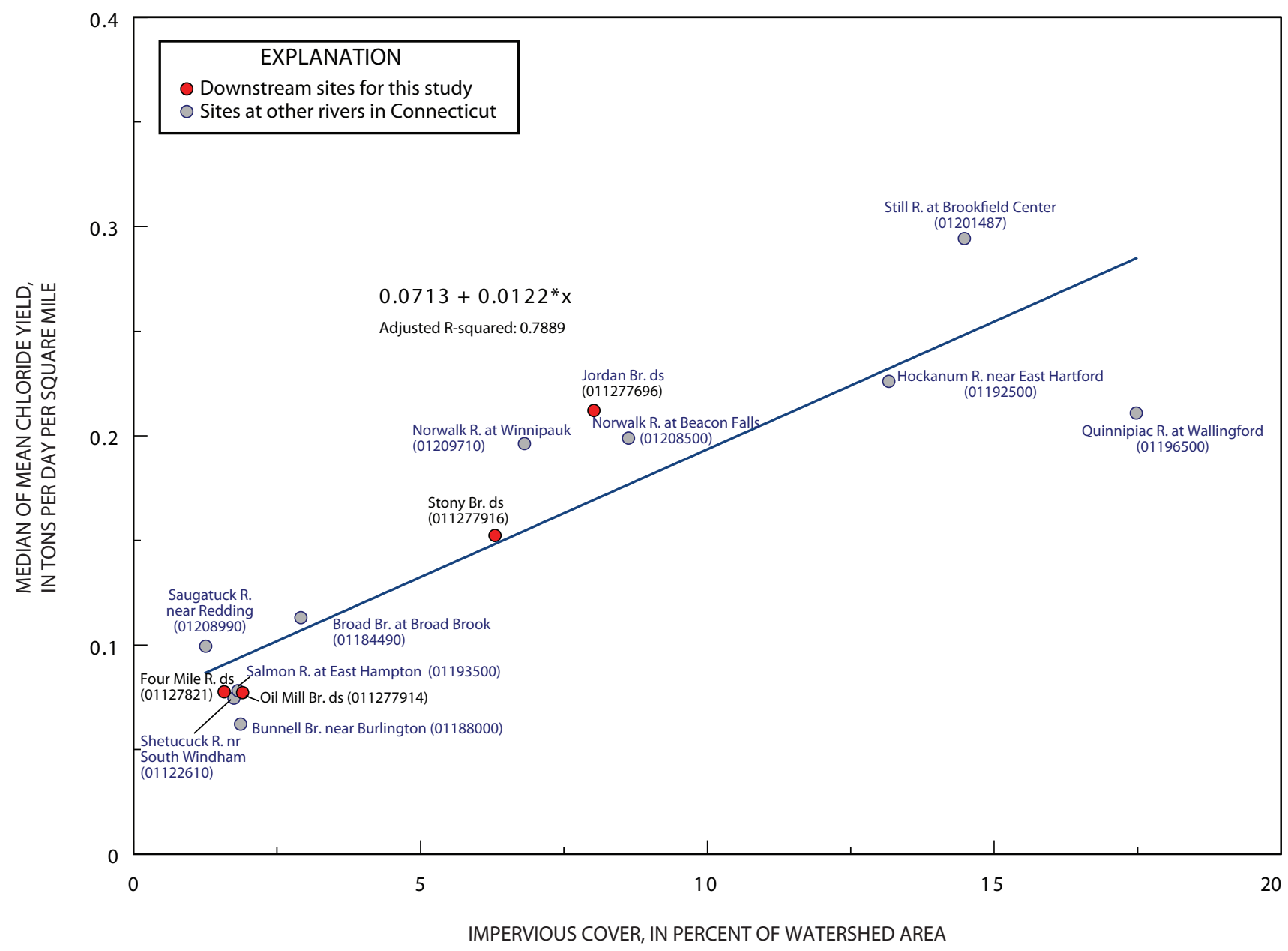

Figure 17. Percentage of impervious cover as a function of (1) the chloride yields for the downstream monitoring stations at Four Mile River, Oil Mill Brook, Stony Brook, and Jordan Brook during the periods of record for this study, and (2) the median of the mean chloride yields at other selected rivers in Connecticut during water years 1998-2007. (Impervious cover data from National Land Cover Database, (U.S. Environmental Protection Agency, 2001; R., River; Br., Brook; ds, downstream) 


\section{Summary and Conclusions}

The U.S. Geological Survey, the Connecticut Department of Transportation, and the Federal Highway Administration conducted a cooperative study to evaluate potential effects of road-salt application on the quality of stream water in four watersheds crossed by Interstate 95 (I-95) in southeastern Connecticut. The results of the study will be considered in an Environmental Impact Statement (EIS) for the expansion of I-95 between Old Lyme and New London, Conn.

Streamflow and water quality were studied at four selected watersheds-Four Mile River, Oil Mill Brook, Stony Brook, and Jordan Brook. Streamgages were instrumented and maintained at downstream sites, and continuous water-quality monitors were installed and maintained at upstream and downstream sites. Water quality was assessed by analyzing the dissolved ions in grab samples and by continuous recording of data from water temperature, specific conductance, and pH sensors. Grab samples were collected (1) during winter stormwater-runoff events, such as winter storms or subsequent periods of rain or warm temperatures in which melting takes place, (2) approximately monthly during routine conditions and analyzed for chloride concentrations and specific conductance, and (3) during base-flow conditions and analyzed for major ions and concentrations of dissolved $\mathrm{Fe}$, $\mathrm{Mn}$, and $\mathrm{Br}$.

Chloride $(\mathrm{Cl})$ concentrations at the eight water-quality monitoring sites were well below the U.S. Environmental Protection Agency (USEPA) recommended chronic and acute $\mathrm{Cl}$ toxicity criteria for aquatic life. Specific conductance and estimated $\mathrm{Cl}$ concentrations in streams, particularly at sites downstream from I-95, increased during discharge events in the winter and early spring as a result of deicers applied to roads and washed off by stormwater or meltwater. During winter storms, deicing activities, or subsequent periods of melting, specific conductance peaked as high as 703 microsiemens per centimeter (160 milligrams per liter estimated $\mathrm{Cl}$ concentration) at the Oil Mill Brook downstream site.

$\mathrm{Cl}$ loads in streams generally were highest in the winter and early spring. The estimated daily yield for the four monitoring sites downstream from Interstate 95 ranged from 0.07 ton per day per square mile $\left((\operatorname{ton} / \mathrm{d}) / \mathrm{mi}^{2}\right)$ for the least developed watershed to 0.21 (ton $/ \mathrm{d}) / \mathrm{mi}^{2}$ for the watershed with the highest percentage of urban development and impervious surfaces. The $\mathrm{Cl}$ load from atmospheric deposition was estimated on the basis of ranges of concentrations measured at National Atmospheric Deposition Program stations in Lexington, Mass.; Abington, Conn.; and Cedar Beach, N.Y. The estimated median contribution of $\mathrm{Cl}$ from atmospheric deposition ranged from 4.3 percent of $\mathrm{Cl}$ load at the Oil Mill Brook-Stony Brook-Jordan Brook study area to 7.1 percent at the Four Mile River watershed. A comparison of the $\mathrm{Cl}$ load estimated inputs and outputs indicates that more $\mathrm{Cl}$ is entering the watersheds through atmospheric deposition and application of deicers than is leaving in streams. The lag time between introduction of $\mathrm{Cl}$ to the watershed and transport to the stream, and uncertainty in the load estimates may be the cause of this discrepancy. In addition, estimates of direct infiltration of $\mathrm{Cl}$ to groundwater that originates from atmospheric deposition, deicer applications, septic-tank drainfields, and other sources to groundwater were not within the scope of this project.

$\mathrm{Cl}$ yields at the downstream monitoring stations at Four Mile River, Oil Mill Brook, Stony Brook, and Jordan Brook were compared with annual $\mathrm{Cl}$ yield estimates for 10 selected rivers in Connecticut, which were generated using LOADEST. Four Mile River and Oil Mill Brook had low estimated Cl yields similar to yields at Bunnell (Burlington) Brook and Shetucket River, reflecting the low percentages of developed land and impervious area. Jordan Brook and Stony Brook had relatively high estimated $\mathrm{Cl}$ yields, but not as high as more urbanized watersheds such as those of the Still River at Brookfield Center and the Hockanum River. $\mathrm{Cl}$ yields for these sites were positively correlated with the percentage of impervious cover, probably reflecting the application of deicers to roadways, as well as sources and practices associated with greater impervious cover, such as wastewater and septic-system discharges, and leachate from landfills and salt-storage areas.

\section{Acknowledgments}

The authors would like to thank Robert Turner, Eloise Powell, and Patricia Cazenas of FHWA, Paul Corrente and Kevin Carifa of Connecticut Department of Transportation, and the Connecticut Academy of Science and Engineering team for technical input and guidance and for providing data or information. In addition, the authors would like to thank U.S. Geological Survey employees Joseph Martin, Dan Lolos, Timothy Sargent, and Timothy Frick for maintenance of streamgages and water-quality monitors, and collection of water-quality samples.

\section{References Cited}

Bubeck, R.C., Diment, W.H., Deck, B.L., Baldwin, A.L., and Lipton, S.D., 1971, Runoff of deicing salt-Effect on Irondequoit Bay, Rochester, New York: Science, v. 172, p. $1128-1132$.

Chabaeva, A.A., Civco, D.L., and Prisloe, S., 2004, Development of a population and land use based regression model to calculate the amount of imperviousness, in Proceedings, 2004 ASPRS conference, Denver, Colorado, 24-28 May: 9 p., accessed September 10, 2009, at http:// nemo.uconn.edu/tools/impervious_surfaces/pdfs/Chabaeva_ etal_2004.pdf. 
Church, P.E., and Friesz, P.J., 1993, Effectiveness of highwaydrainage systems in preventing road-salt contamination of groundwater-Preliminary findings: Transportation Research Record, v. 1420, p. 56-64.

Colombo, M.J., and Trench, E.C.T., 2002, Trends in surfacewater quality in Connecticut: U.S. Geological Survey Water-Resources Investigations Report 02-4012, 39 p.

Connecticut Department of Transportation, 2009, Interim snow \& ice guidelines-2008-09: Connecticut Department of Transportation, Bureau of Engineering \& Highway Operations, $53 \mathrm{p}$.

Connecticut Department of Environmental Protection, 1995, Leachate and wastewater discharge inventory: Hartford, Connecticut, Connecticut Department of Environmental Protection, Environmental and Geographic Information Center, Digital Shapefile, 1:50,000, accessed September 10, 2009, at http://www.ct.gov/dep/cwp/view. $\operatorname{asp}$ ? $=2698 \& Q=322898$.

Connecticut Department of Environmental Protection, 2009, CTDEP Proposed Revisions to Connecticut Water Quality Standards, December 22, accessed November 1, 2009, at http://www.ct.gov/dep/lib/dep/ water/water_quality_standards/water_quality_standards_ proposed_12_22_09.pdf.

Denner, J.C., Clark, S.F., Jr., Smith, T.E., and Medalie, Laura, 2010, Effects of highway road salting on the water quality of selected streams in Chittenden County, Vermont, November 2005-2007: U.S. Geological Survey Scientific Investigations Report 2009-5236, 43 p.

Fishman, M.J., and Friedman, L.C., 1989, Methods for determination of inorganic substances in water and fluvial sediments: U.S. Geological Survey Techniques of WaterResources Investigations, book 5, chap. A1, 545 p.

Gay, F.B., and Melching, C.S., 1995, Relation of precipitation quality to storm type, and constituent loads in Massachusetts, 1983-85: U.S. Geological Survey WaterResources Investigations Report 94-4224, 82 p.

Grady, S.J., 1993, Effects of land use on quality of water in stratified-drift aquifers in Connecticut: U.S. Geological Survey Open-File Report 91-200, 87 p.

Grady, S.J., and Mullaney, J.R., 1998, Natural and human factors affecting shallow water quality in surficial aquifers in the Connecticut, Housatonic, and Thames River Basins: U.S. Geological Survey Water-Resources Investigations Report 98-4042, 81 p.
Granato, G.E., Church, P.E., and Stone, V.J., 1995, Mobilization of major and trace constituents of highway runoff in groundwater potentially caused by deicingchemical migration: Washington, D.C., Transportation Research Record 1483, Transportation Research Board, National Research Council, p. 92-104.

Granato, G.E., and Smith, K.P., 1999, Estimating concentrations road-salt constituents in highway-runoff from measurements of specific conductance: U.S. Geological Survey Water-Resources Investigations Report 99-4077, 22 p.

Gurnell, A.M., Brown, G.H., and Tranter, M., 1994, Sampling strategy to describe the temporal hydrochemical characteristics of an alpine proglacial stream: Hydrological Processes, v. 8, p. 1-25.

Howard, K.W.F., and Haynes, J., 1993, Groundwater contamination due to road de-icing chemicals - Salt balance implications: Geoscience Canada, v. 20, p. 1-8.

Kaushal, S.S., Groffman, P.M., Likens, G.E., Belt, K.T., Stack, W.P., Kelly, V.R., Band, L.E., and Fisher, G.T., 2005, Increased salinization of fresh water in the northeastern United States: Proceedings National Academy of Sciences, v. 102 , p. $13517-13520$.

Kelly, W.R., Panno, S.V., Hackley, K.C., Hwang, Hue-Hwa, Marinsek, A.T., and Markus, Momcilo, 2010, Using chloride and other ions to trace sewage and road salt in the Illinois Waterway: Applied Geochemistry, v. 25, p. 661-673.

Kostick, D.S., Milanovich, J.A., and Coleman, R.R., 2007, 2005 Minerals Yearbook-Salt: U.S. Geological Survey, March 2007, accessed November 1, 2009, at http://minerals. er.usgs.gov/minerals/pubs/commodity/salt/salt_myb05.pdf.

Kostick, D.S., 1993, The material flow of salt: U.S. Department of the Interior, Bureau of Mines, Information Circular 9343, 32 p.

Melvin, R.L., and Bingham, J.W., 1991, Availability of water from stratified-drift aquifers in the Farmington River valley, Simsbury, Connecticut: U.S. Geological Survey WaterResources Investigations Report 89-4140, 77 p.

Miller, D.R., Warner, G.S., Ogden, F.L., and DeGaetano, A.T., 2002, Precipitation in Connecticut: Connecticut Institute of Water Resources Special Reports, 65 p.

Mullaney, J.R., Lorenz, D.L., and Arntson, A.D., 2009, Chloride in groundwater and surface water in areas underlain by the glacial aquifer system, northern United States: U.S. Geological Survey Scientific Investigations Report 2009-5086, 41 p. 
National Atmospheric Deposition Program (NRSP-3), 2009, Monitoring our changing chemical climate: Champaign, Ill., NADP Program Office, Illinois State Water Survey (http://nadp.sws.uiuc.edu).

National Operational Hydrologic Remote Sensing Center, 2005, Overview of the center's web site and products: National Weather Service, National Oceanic and Atmospheric Administration, U.S. Department of Commerce, Minneapolis, Minnesota, 15 p. (http://www. nohrsc.noaa.gov/technology/pdf/NOHRSC_web_overview. pdf)

Prisloe, M., Wilson, E.H., Arnold, C., 2003, Final reportRefinement of population-calibrated land-cover-specific impervious surface coefficients for Connecticut: Nemo FY02 Workplan, DEP project 01-08, University of Connecticut, Middlesex County Extension Center, 20 p.

Ramakrishna, D.M., and Viraraghavan, T., 2005, Environmental impact of chemical deicers-A review: Water Air Soil Pollution, v. 166, p. 49-63.

Rantz, S.E., and others, 1982, Measurement and computation of streamflow_-volume 1. Measurement of stage and discharge: U.S. Geological Survey Water-Supply Paper 2175,284 p.

Runkel, R.L., Crawford, C.G., and Cohn, T.A., 2004, Load estimator (LOADEST) -A FORTRAN program for estimating constituent loads in streams and rivers: U.S. Geological Survey Techniques and Methods, book 4, chap. A5, 69 p.

Sears Ecological Applications Co, LLC, 2009, Material safety data sheet: 2 p., accessed on January 20, 2010, at http:// www.seaco.com/images/MSDS\%20IBG\%20II\%2020.pdf.

Smith, R.A., Alexander, R.B., and Wolman, M.G., 1987, Water-quality trends in the Nations's Rivers: Science, v. 235 , p. $1607-1615$.

Stone, J.R., Schafer, J.P., London, E.H., and Thompson, W.B., 1992, Surficial materials map of Connecticut: U.S. Geological Special Map, scale 1:125,000, 2 sheets.

Toler, L.G., and Pollock, S.J., 1974, Retention of chloride in the unsaturated zone: U.S. Geological Survey Journal of Research, v. 2, no. 1, p. 119-123.
Trench, E.C.T., 1996, Trends in surface-water quality in Connecticut, 1969-88: U.S. Geological Survey WaterResources Investigations Report 96-4161, 176 p.

University of Connecticut, 2009, Center for Land Use Education And Research (CLEAR): College of Agriculture \& Natural Resources, accessed May 2, 2009, at http://clear. uconn.edu/projects/landscape/category_description.htm.

U.S. Environmental Protection Agency, 1988, Ambient water quality criteria for chloride-1988: Duluth, Minn., Office of Research and Development, Environmental Research Laboratory, EPA 440588001.

U.S. Environmental Protection Agency, 1992, Secondary Drinking Water Regulations-Guidance for Nuisance Chemicals: EPA 810/K-92-001, accessed June 13, 2006, at http://www.epa.gov/safewater/consumer/2ndstandards.html.

U.S. Environmental Protection Agency, 2001, 2001 National Land Cover Data: Multi-Resolution Land Characteristics Consortium, accessed February 1, 2010, at http://www.epa. gov/mrlc/nlcd-2001.html.

Vogelmann, J.E., Sohl, T.L., Campbell, P.V., Shaw, D.M., 1998, Regional land cover characterization using LANDSAT thematic mapper data and ancillary data sources: Environmental Monitoring and Assessment, v. 51, p. 415-428.

Wagner, R.J., Boulger, R.W., Jr., Oblinger, C.J., and Smith, B.A., 2006, Guidelines and standard procedures for continuous water-quality monitors-Station operation, record computation, and data reporting: U.S. Geological Survey Techniques and Methods 1-D3, 51 p., plus 8 attachments, accessed April 10, 2006, at http://pubs.water. usgs.gov/tm1d 3 .

Wilde, F.D., ed., 2004, Cleaning of equipment for water sampling (ver. 2.0): U.S. Geological Survey Techniques of Water-Resources Investigations, book 9, chap. A3, April, accessed March 17, 2009, at http://pubs.water.usgs.gov/ twri9A3/.

Wilde, F.D., 2005, Preparations for water sampling: U.S. Geological Survey Techniques of Water-Resources Investigations, book 9, chap. A1, January, accessed March 17, 2009, at http://pubs.water.usgs.gov/twri9A1/.

Wulkowicz, G.M., and Saleem, Z.A., 1974, Chloride balance of an urban basin in the Chicago area: Water Resources Research, v. 10, no. 5, p. 974-982. 
Appendix 1. Specific conductance and chloride concentrations in water samples from upstream and downstream monitoring sites at Four Mile River, Oil Mill Brook, Stony Brook, and Jordan Brook, southeastern Connecticut, November 2008 to January 2010.

[ID, identifier; $\mu \mathrm{S} / \mathrm{cm}$, microsiemens per centimeter at 25 degrees Celsius; $\mathrm{mg} / \mathrm{L}$, milligrams per liter]

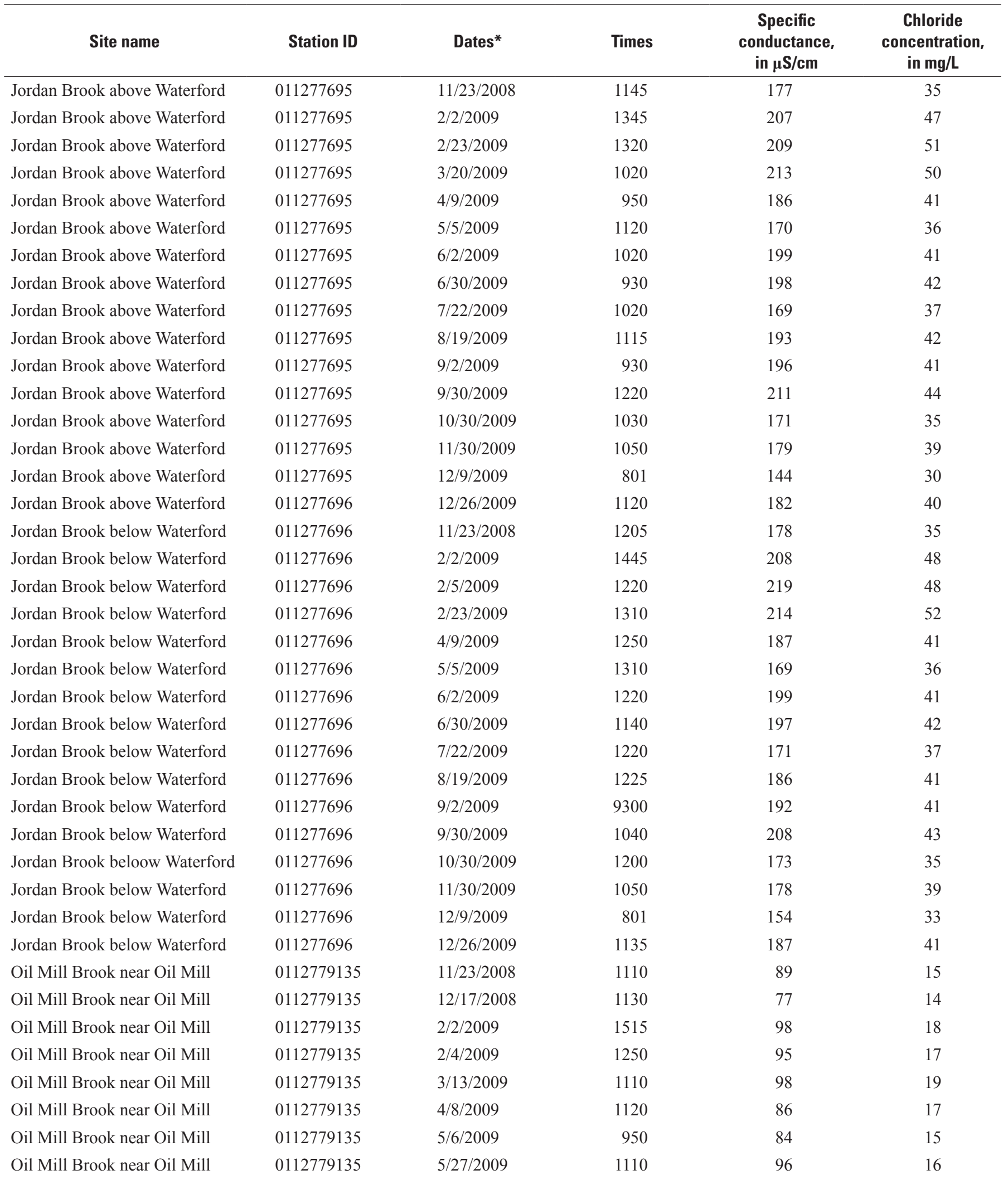


Appendix 1. Specific conductance and chloride concentrations in water samples from upstream and downstream monitoring sites at Four Mile River, Oil Mill Brook, Stony Brook, and Jordan Brook, southeastern Connecticut, November 2008 to January 2010.

[ID, identifier; $\mu \mathrm{S} / \mathrm{cm}$, microsiemens per centimeter at 25 degrees Celsius; $\mathrm{mg} / \mathrm{L}$, milligrams per liter]

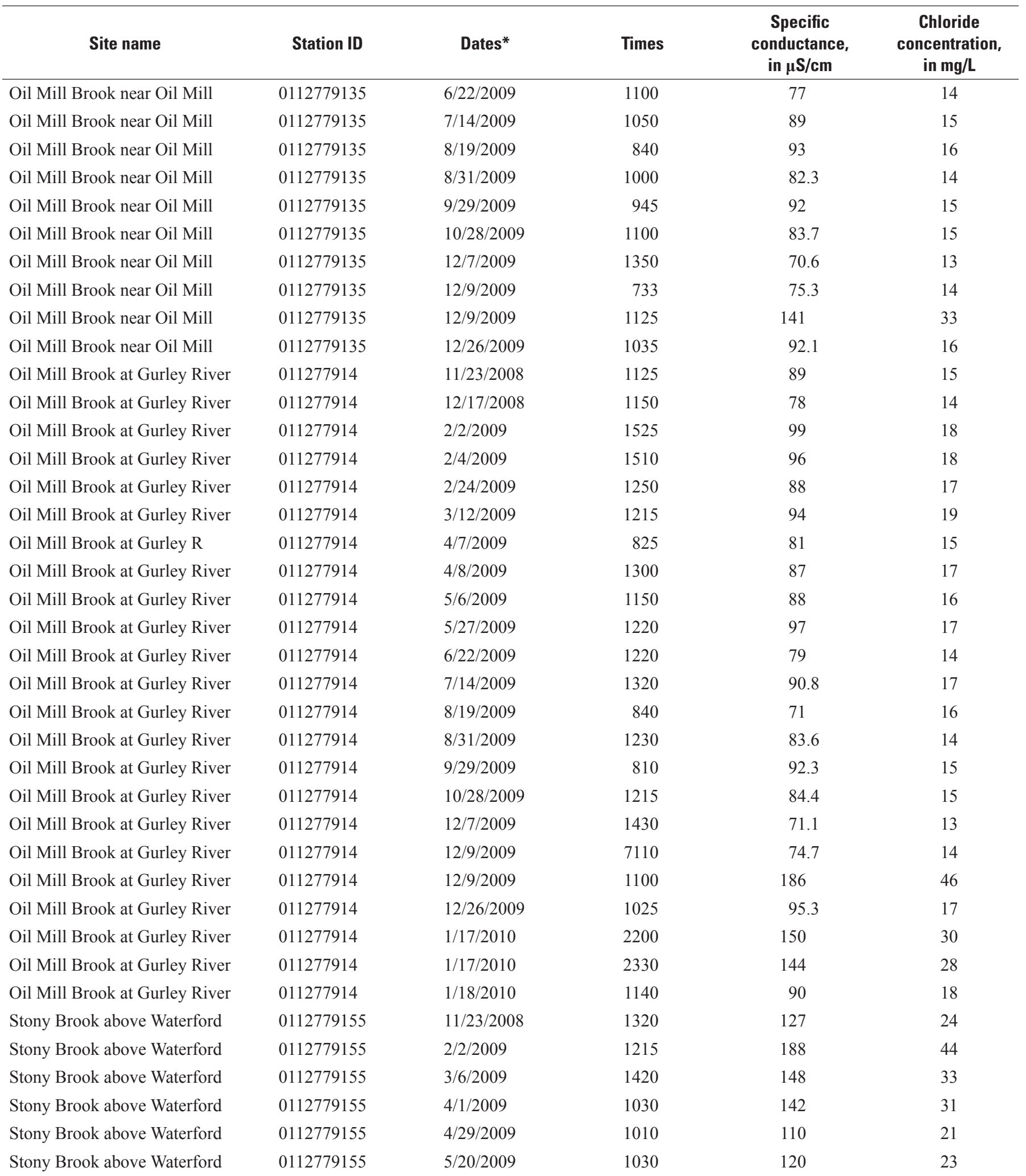


Appendix 1. Specific conductance and chloride concentrations in water samples from upstream and downstream monitoring sites at Four Mile River, Oil Mill Brook, Stony Brook, and Jordan Brook, southeastern Connecticut, November 2008 to January 2010.

[ID, identifier; $\mu \mathrm{S} / \mathrm{cm}$, microsiemens per centimeter at 25 degrees Celsius; $\mathrm{mg} / \mathrm{L}$, milligrams per liter]

\begin{tabular}{|c|c|c|c|c|c|}
\hline Site name & Station ID & Dates* & Times & $\begin{array}{c}\text { Specific } \\
\text { conductance, } \\
\text { in } \mu \mathrm{S} / \mathrm{cm}\end{array}$ & $\begin{array}{c}\text { Chloride } \\
\text { concentration, } \\
\text { in } \mathrm{mg} / \mathrm{L}\end{array}$ \\
\hline Stony Brook above Waterford & 0112779155 & $6 / 8 / 2009$ & 1030 & 148 & 28 \\
\hline Stony Brook above Waterford & 0112779155 & $7 / 1 / 2009$ & 1050 & 135 & 24 \\
\hline Stony Brook above Waterford & 0112779155 & $7 / 20 / 2009$ & 1140 & 145 & 26 \\
\hline Stony Brook above Waterford & 0112779155 & $8 / 19 / 2009$ & 1302 & 131 & 24 \\
\hline Stony Brook above Waterford & 0112779155 & $9 / 28 / 2009$ & 900 & 214 & 47 \\
\hline Stony Brook above Waterford & 0112779155 & $10 / 26 / 2009$ & 1115 & 121 & 23 \\
\hline Stony Brook above Waterford & 0112779155 & $11 / 30 / 2009$ & 1220 & 110 & 22 \\
\hline Stony Brook above Waterford & 0112779155 & $12 / 9 / 2009$ & 902 & 121 & 27 \\
\hline Stony Brook at Route 1 & 011277916 & $2 / 2 / 2009$ & 1500 & 165 & 35 \\
\hline Stony Brook at Route 1 & 011277916 & $2 / 6 / 2009$ & 1220 & 157 & 31 \\
\hline Stony Brook at Route 1 & 011277916 & $2 / 24 / 2009$ & 1455 & 141 & 31 \\
\hline Stony Brook at Route 1 & 011277916 & $3 / 6 / 2009$ & 1235 & 142 & 30 \\
\hline Stony Brook at Route 1 & 011277916 & $3 / 12 / 2009$ & 1310 & 138 & 30 \\
\hline Stony Brook at Route 1 & 011277916 & $4 / 1 / 2009$ & 1210 & 144 & 30 \\
\hline Stony Brook at Route 1 & 011277916 & 4/7/2009 & 750 & 144 & 28 \\
\hline Stony Brook at Route 1 & 011277916 & $4 / 29 / 2009$ & 1250 & 128 & 24 \\
\hline Stony Brook at Route 1 & 011277916 & $5 / 20 / 2009$ & 1130 & 131 & 25 \\
\hline Stony Brook at Route 1 & 011277916 & $10 / 26 / 2009$ & 1230 & 128 & 24 \\
\hline Stony Brook at Route 1 & 011277916 & $11 / 30 / 2009$ & 1330 & 125 & 24 \\
\hline Stony Brook at Route 1 & 011277916 & $12 / 9 / 2009$ & 933 & 179 & 42 \\
\hline Stony Brook at Route 1 & 011277916 & $12 / 9 / 2009$ & 1030 & 215 & 48 \\
\hline Stony Brook at Route 1 & 011277916 & $12 / 26 / 2009$ & 1155 & 124 & 23 \\
\hline Four Mile River above I-95 & 01127819 & $11 / 23 / 2008$ & 910 & 84 & 11 \\
\hline Four Mile River above I-95 & 01127819 & $1 / 23 / 2009$ & 1040 & 85 & 10 \\
\hline Four Mile River above I-95 & 01127819 & $2 / 2 / 2009$ & 1545 & 83 & 11 \\
\hline Four Mile River above I-95 & 01127819 & $2 / 25 / 2009$ & 1220 & 78 & 11 \\
\hline Four Mile River above I-95 & 01127819 & $3 / 31 / 2009$ & 1200 & 92 & 14 \\
\hline Four Mile River above I-95 & 01127819 & $5 / 1 / 2009$ & 1050 & 79 & 10 \\
\hline Four Mile River above I-95 & 01127819 & $5 / 21 / 2009$ & 1045 & 88 & 12 \\
\hline
\end{tabular}


Appendix 1. Specific conductance and chloride concentrations in water samples from upstream and downstream monitoring sites at Four Mile River, Oil Mill Brook, Stony Brook, and Jordan Brook, southeastern Connecticut, November 2008 to January 2010.

[ID, identifier; $\mu \mathrm{S} / \mathrm{cm}$, microsiemens per centimeter at 25 degrees Celsius; $\mathrm{mg} / \mathrm{L}$, milligrams per liter]

\begin{tabular}{|c|c|c|c|c|c|}
\hline Site name & Station ID & Dates* & Times & $\begin{array}{c}\text { Specific } \\
\text { conductance, } \\
\text { in } \mu S / \mathrm{cm}\end{array}$ & $\begin{array}{c}\text { Chloride } \\
\text { concentration, } \\
\text { in } \mathrm{mg} / \mathrm{L}\end{array}$ \\
\hline Four Mile River above I-95 & 01127819 & $6 / 19 / 2009$ & 1120 & 67 & 9 \\
\hline Four Mile River above I-95 & 01127819 & $7 / 8 / 2009$ & 1020 & 64 & 8 \\
\hline Four Mile River above I-95 & 01127819 & $7 / 29 / 2009$ & 1040 & 64 & 7 \\
\hline Four Mile River above I-95 & 01127819 & $8 / 19 / 2008$ & 1000 & 98 & 11 \\
\hline Four Mile River above I-95 & 01127819 & $10 / 6 / 2009$ & 920 & 90.1 & 11 \\
\hline Four Mile River above I-95 & 01127819 & $11 / 2 / 2009$ & 1030 & 79.6 & 9.9 \\
\hline Four Mile River above I-95 & 01127819 & $12 / 7 / 2009$ & 1115 & 63.6 & 8.6 \\
\hline Four Mile River above I-95 & 01127819 & $12 / 9 / 2009$ & 1011 & 72.2 & 11 \\
\hline Four Mile River below I-95 & 01127821 & $1 / 23 / 2009$ & 1215 & 90 & 12 \\
\hline Four Mile River below I-95 & 01127821 & $2 / 2 / 2009$ & 1550 & 91 & 13 \\
\hline Four Mile River below I-95 & 01127821 & 2/11/2009 & 1150 & 89 & 13 \\
\hline Four Mile River below I-95 & 01127821 & $2 / 25 / 2009$ & 1545 & 86 & 13 \\
\hline Four Mile River below I-95 & 01127821 & $3 / 31 / 2009$ & 1400 & 92 & 13 \\
\hline Four Mile River below I-95 & 01127821 & $5 / 1 / 2009$ & 1200 & 89 & 12 \\
\hline Four Mile River below I-95 & 01127821 & $5 / 21 / 2009$ & 1140 & 88 & 12 \\
\hline Four Mile River below I-95 & 01127821 & $6 / 19 / 2009$ & 1330 & 73 & 10 \\
\hline Four Mile River below I-95 & 01127821 & $7 / 8 / 2009$ & 1150 & 66 & 8.8 \\
\hline Four Mile River below I-95 & 01127821 & $12 / 9 / 2009$ & 1029 & 86.8 & 15 \\
\hline Four Mile River below I-95 & 01127821 & $12 / 9 / 2009$ & 1250 & 78 & 13 \\
\hline Four Mile River below I-95 & 01127821 & $1 / 17 / 2010$ & 2130 & 157 & 26 \\
\hline Four Mile River below I-95 & 01127821 & $1 / 17 / 2010$ & 2200 & 147 & 23 \\
\hline
\end{tabular}

"The actual study period is November 2008 to September 2009; a longer period of record was included to improve the regression model. 
This page has been left blank intentionally. 
Prepared by the Pembroke and West Trenton Publishing Service Centers.

For more information concerning this report, contact:

Director

U.S. Geological Survey

Connecticut Water Science Center

101 Pitkin Street

East Hartford, CT 06108

dc_ct@usgs.gov

or visit our Web site at:

http://ct.water.usgs.gov 


\section{兑}

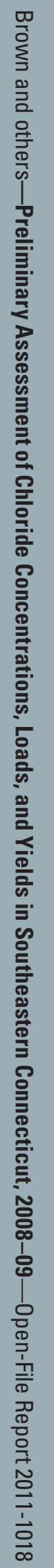

